\title{
PRELÚDIO A HISTÓRIA DO NOTARIADO PÚBLICO EM PERPIGNAN E NO CONDADO DE ROUSSILLON (1184-1340)*
}

\author{
PRELUDE A L'HISTOIRE DU NOTARIAT PUBLIC A PERPIGNAN ET DANS LE \\ COMTE DE ROUSSILLON
}

$(1184-1340)^{* *}$

Prof. Dr. Rodrigue TRÉTON***

\section{RESUMO:}

Nos estados cristãos do Ocidente mediterrânico, o notariado apareceu no século XII quando o escrevente da Alta Idade Média se tornara um oficial instituído pela autoridade pública, possuindo a capacidade simbólica, pela invenção do signum, de conferir um caráter autêntico a suas escrituras, preliminares (notas e breves) ou elaboradas (mundum, instrumento). A conservação de livros de ata, propriedade do notário e de seus herdeiros, permitia a preservação do registro completo ou de seu extrato muito tempo após a primeira redação. Em matéria de direito privado, essa inovação, consecutiva à renovação do direito romano, devia substituir vantajosamente o antigo procedimento, complexo, aleatório e limitado a certo tempo, da autenticação pela prova testemunhal. O empreendimento de descrever os primeiros tempos do notariado público no condado de Roussillon não é uma tarefa cômoda, principalmente em razão das carências da documentação, que se mostram, deste ponto de vista, particularmente incapacitantes. Não subsiste, de fato, nos arquivos locais, qualquer texto legislativo ou administrativo se referindo, de algum modo, à regulamentação e às condições de exercício deste ofício antes da metade do século XIII. Para este período inicial, que consiste na data de aparição da instituição notarial, seguindo sua difusão e buscando conhecer as primeiras etapas de sua evolução, a história somente tem o recurso de se apoiar no estudo diplomático dos registros privados. Trata-se, por consequência, de um trabalho particularmente extenso, consistindo em examinar atentamente as fórmulas da autenticação dos documentos da prática, a fim de discernir modificações ou variações significativas, suscetíveis de nos informar sobre as primeiras etapas da organização do ofício público. Foi a partir do reinado de Jaime Ide Aragão que apareceram os primeiros regulamentos visando enquadrar a prática notarial. Iniciava-se, então, um segundo período, cobrindo a segunda metade do século XIII e a primeira metade do século XIV, para o qual dispomos de um corpus de textos normativos que testemunham a natureza das questões ligadas ao controle de um ofício essencial, cujos profissionais, notários e escreventes públicos, tinham por principal função garantir a legalidade das transações econômicas e sociais de uma população eminentemente contratual e de preservar fielmente a memória disso.

\footnotetext{
** Traduzido pelo Prof. Dr. Bruno Tadeu Salles (UEG/UFG).

*** Doutor em História e Pesquisador: FRAMESPA: UMR 5136 - França (Toulouse/França). E-mail: rodrigue.treton@free.fr
} 


\section{PALAVRAS-CHAVE:}

Notariado Público; Instituição; Prosopografia; Roussillon; Perpignan.

\section{ABSTRACT:}

In the christian states of the mediterranean West, the notary appeared on the 12th century when the scribe of the High Middle Age has turned into an official set by the public authority, possessing the symbolic capacity, through the invention of signum, to confer an authentic character to your scriptures, preliminaries (notes and briefings) or elaborate ones (mundum, instrument). The conservation of record books, property of the notary and of its inheritors, would allow the preservation of the complete registry or of your extract a long time after the first redaction. When it comes to private law, this inovation, consecutive to the renewal of the roman law, should replace advantageously the old procedure, which was complex, random and limited to a certain time, of the authentication through the $\mathrm{w}$ itness test. The enterprise of describing the first moments of the public notary at the county of Roussillon is not a comfortable task, mostly because of the shortage of documentation, which show, from this point of view, particularly crippling.In fact, it doesn't subsist, in the local archives, any legislative or administrative text referring itself, in some way, about the regularization and the exercising conditions of that office before half of the 13th century. For this initial period, which consists on the apparition date of the notary institution, following its difusion and seeking knowledge about the first steps of your evolution, the history only has the resource to support the diplomatic study of the private records. As a consequence, it's about a particularly extense work, consisting on examining closely the authentication formulas of the practice documents, intending to discern modifications or significative variations, susceptible to inform us about the $\mathrm{f}$ irst organization steps of the public office. It started with the reign of Jaime Ide Aragão, when the first regulations appeared, seeking to frame the notary practice. Therefore, it was starting a second period, covering the second half of the 13th century and the first half of the 14th century, to which we disposed of a corpus of normative texts which wtiness the nature of questions connected to the control of an essential office, which all of the professionals, notaries and public scribes, had the function to guarantee the legality of the social and economic transactions of a population that is eminently contractual and to preserve accurately all of its memory.

\section{KEY-WORDS:}

Public Notariat; Institution; Prosopographie; Roussillon; Perpignan.

Nos estados cristãos do Ocidente mediterrânico, o notariado apareceu no século XII quando o escrevente da Alta Idade Média se tornara um oficial instituído pela autoridade pública, possuindo a capacidade simbólica, pela invenção do signum, de conferir um caráter autêntico a suas escrituras, preliminares (notas e breves) ou elaboradas (mundum, instrumento). A conservação de livros de ata, propriedade do notário e de seus herdeiros, permitia a preservação do registro completo ou de seu extrato muito tempo após a primeira redação ${ }^{1}$. Em matéria de direito privado, essa inovação, consecutiva à renovação do direito 


\section{PRELÚDIO A HISTÓRIA DO NOTARIADO PÚBLICO EM PERPIGNAN E NO}

CONDADO DE ROUSSILLON (1184-1340)

romano, devia substituir vantajosamente o antigo procedimento, complexo, aleatório e limitado a certo tempo, da autenticação pela prova testemunhal ${ }^{2}$.

A despeito de sua riqueza intrínseca e de sua importância fundamental para a compreensão dos fatos históricos, a história do direito e das instituições medievais do condado de Roussillon tem suscitado, até então, um número muito restrito de publicações ${ }^{3}$. Essa deficiência da historiografia local é mais gritante quando contrastada com a profusão e a riqueza dos estudos consagrados a essas matérias fundamentais nas $\operatorname{comarcas}^{4}$ catalãs situadas ao sul dos Pirineus ${ }^{5}$. A história do notariado dos condados norte-catalães não escapa, infelizmente, a essa regra. É apenas muito recentemente que os pesquisadores têm, de fato, começado a explorar esse assunto ${ }^{6}$.

O empreendimento de descrever os primeiros tempos do notariado público no condado de Roussillon não é uma tarefa cômoda, principalmente em razão das carências da documentação, que se mostram, deste ponto de vista, particularmente incapacitantes. Não subsiste, de fato, nos arquivos locais, qualquer texto legislativo ou administrativo se referindo, de algum modo, à regulamentação e às condições de exercício deste ofício antes da metade do século XIII.

Para este período inicial, que consiste na data de aparição da instituição notarial, seguindo sua difusão e buscando conhecer as primeiras etapas de sua evolução, a história somente tem o recurso de se apoiar no estudo diplomático dos registros privados ${ }^{7}$. Trata-se, por consequência, de um trabalho particularmente extenso, consistindo em examinar atentamente as fórmulas da autenticação dos documentos da prática, a fim de discernir modificações ou variações significativas, suscetíveis de nos informar sobre as primeiras etapas da organização do ofício público.

Foi a partir do reinado de Jaime I de Aragão que apareceram os primeiros regulamentos visando enquadrar a prática notarial. Iniciava-se, então, um segundo período, cobrindo a segunda metade do século XIII e a primeira metade do século XIV, para o qual dispomos de um corpus de textos normativos que testemunham a natureza das questões ligadas ao controle de um ofício essencial, cujos profissionais, notários e escreventes públicos, tinham por principal função garantir a legalidade das transações econômicas e sociais de uma população eminentemente contratual e de preservar fielmente a memória disso.

O exame combinado dos escatocolos dos documentos privados e das fontes normativas nos revela principalmente os tempos fortes que marcam o estabelecimento do notariado público no condado de Roussillon, desde sua introdução em Perpignan sob o 
reinado de Afonso II de Aragão, em 1184, até a reforma do notariado ordenada pelo rei de Mallorca, Jaime III, em $1340^{8}$. São os primeiros resultados de uma pesquisa a prosseguir que propusemos apresentar nas linhas seguintes. Estas constatações preliminares não têm, de fato, a pretensão de esgotar um tema tão rico quanto complexo; elas visam simplesmente a abrir caminho para futuras investigações que esperamos aparecerem para afinar e enriquecer nossos poucos conhecimentos sobre o assunto.

\section{A RECEPÇÃO DO DIREITO ROMANO NO SÉCULO XII}

A introdução do notariado público constituiu, com a aparição do consulado, uma das manifestações institucionais mais evidentes da recepção do direito romano nos principados do sul da França e da Catalunha ao curso da segunda metade do século XII. Elemento primordial, cujas múltiplas implicações influenciaram irremediavelmente o curso da evolução da civilização ocidental, o ensino dos doutores que são docentes no Studium de Bologna se difundira inicialmente nos capítulos catedrais, antes de ganhar os principais centros urbanos que pontuavam as grandes vias, marítimas e terrestres, do comércio mediterrânico 9 .

As relações mercantis mantidas com os negociatores pisanos, depois genoveses, que frequentavam assiduamente o litoral catalão nos primórdios do século XII, tiveram, verdadeiramente, um papel determinante na difusão precoce do direito erudito em Barcelona e nas cidades da velha Catalunha (ZIMMERMAN, 2003, p. 11-19). Aqui, o enxerto do direito de Justiniano se converteu no tronco vigoroso de uma sólida tradição legalista de inspiração romanizante. Desta profunda cultura jurídica, são testemunhas as numerosas referências feitas ao código visigótico - o Forum judicum compilado em 649-652 sob o reinado de Recesvindo - nos registros da prática até o final do primeiro terço do século XII (ZIMMERMAN, $2003)^{10}$. As elites catalãs mantiveram a tradição do contrato escrito, mesmo nas horas mais caóticas da transição feudal.

O abandono definitivo das referências ao código visigótico, que interveio nos idos de 1130-1140, marcou uma mudança significativa das práticas do escrito, coincidindo com a adoção pelos escreventes meridionais de novas fórmulas - ou pelo menos de um novo vocabulário jurídico - importadas da Itália setentrional (GOURON, 1957, p. 111). Esta ruptura cultural coaduna-se significativamente com o aparecimento, nas cortes meridionais, dos primeiros especialistas em direito. Dentre eles, alguns, às vezes, precisam sua origem transalpina, lombarda ou ligúria, em regra geral. Este é, igualmente, o momento onde os R. Fac. Dir. UFG, v. 39, n.2, p. 43 - 86, jul. / dez. 2015 
primeiros notários fazem sua entrada nas chancelarias eclesiásticas e principescas do Midi mediterrânico (CARRERAS Y CANDI, 1913, p. 753). Desde 1129, o conde de Barcelona, Raimundo Berengário III, recorria aos serviços de um de seus especialistas, denominado Pôncio (CARRERAS Y CANDI, 1913, p. 753). Sob a impulsão destes primeiros mestres, a prática do direito evoluiu. Este processo de romanização, progressiva, se amplificara a partir do último terço do século XII, quando clérigos catalães de extração nobre ou burguesa, para a maior parte membros dos capítulos catedrais, cada vez mais numerosos, faziam sua formação em direito canônico ou direito civil em contato com os professores da Universidade de Bologna (MIRET I SANS, 1915, p. 137-155; BERTRAN ROIGÉ, 2002-2003; JULIA VIÑAMATA, 2003, p.123-143). Foi neste contexto que o notariado público realizou sua aparição na Catalunha.

\section{OS ESCREVENTES DOS REGISTROS PRIVADOS EM ROUSSILLON NO SÉCULO XII}

Perseguir o aparecimento do notariado público nos documentos medievais roussillonnais consiste essencialmente em recuperar, nas subscrições figurando abaixo das cartas, a emergência de um vocabulário específico para designar seus redatores e/ou seus escreventes, na ocorrência das palavras notarius e tabellio ou da locução scriptor publicus.

No século XII, como nos séculos precedente, se constata que a maior parte dos escreventes em atividade no Roussillon se recrutava no clero. Uma sondagem efetuada sobre uma amostra de 427 registros privados redigidos no condado norte-catalão entre 1100 e 1200 nos informa o nome de cento e quarenta e um profissionais diferentes. Uma esmagadora maioria dos escreventes roussillonnais, próximo de $83 \%$, precisavam seu pertencimento ao estado religioso em suas subscrições. Esta preponderância é pouco surpreendente se se considera que, nessa época, a alfabetização era, quase exclusivamente, reservada aos membros do clero formados nas escolas canonicais ou monásticas.

Se se passa em revista o contingente dos escreventes de registros roussillonnais membros do clero, seguindo uma ordem decrescente de importância, constata-se que cinquenta e três, seja 37,6\%, são padres (sacer, sacerdos, presbyter); trinta, seja $21.3 \%$, são diáconos (diaconus, levita); vinte e um, seja 14,9\%, são monges; sete, seja 5\%, são subdiáconos (subdiaconus); cinco, seja 3,5\%, são clérigos (clericus); seis, seja 2,8\%, são chantres, préchantres ou capiscoles (primicerius, precentor, caputscole); e cinco, 3,5\% são 
mestres de gramática (grammaticus) professando seja no capítulo da catedral Santa Eulália de Elne, seja naquele da colegial de São João de Perpignan. Um deles, chamado Arnaldo, se intitulava grammaticus na parte inferior de dois registros instrumentados em 1170 e 1174 (novo estilo); em seguida, ele abandonou esta designação pelo predicado de magister, como aparece nos sete documentos redigidos por sua mão entre 1177 e $1204^{11}$. O fato que nove dos dez registros instrumentados pelo mestre Arnaldo, que estão conservados, se refiram a paróquia de Torreilles, deixa presumir que este letrado prodigalizava seus ensinamentos na igreja colegial de São Juliano de Torreilles ${ }^{12}$. Enfim, as qualidades de capelão (capellanus), cônego (canonicus) e sacristão somente são reivindicadas uma única vez.

Ocorre que, na corroboração das cartas, os redatores de documentos roussillonnais precisavam, às vezes, seu grau na clericatura e sua função. Assim, sete entre eles se qualificavam simultaneamente de "monacus et presbyter"; dois outros se diziam "diaconus et monacus". Inventaria-se, igualmente, um "clericus et presbyter", um "canonicus et presbyter" e um "diaconus et primicerius". Todos estes casos foram contabilizados duas vezes nas estatísticas precedentes. Com três exceções, os $17 \%$ restantes não forneceram qualquer precisão quanto a seu estatuto social ou profissional. Por essa carência de precisão, é impossível determinar se se trata de pessoas laicas ou de clérigos que não julgaram útil precisar sua condição ${ }^{13}$. Constata-se, em todo caso, que nenhum dos escreventes roussillonnais inventariados se declarou homo laicus. Nós evocamos, todavia, três exceções à regra: a primeira concerne a alguém chamado Petrus, que se intitulava scriba em sua subscrição de uma carta rememorationis de bens tidos em penhor nas paróquias de Toulouges e d'Orle redigida no mês de agosto de $1112^{14}$. É igualmente a qualidade de scriptor que reivindicava Guilelmus, redator da ata de enfeudação de dois mansos situados em Vallcrosa e em Millas consentida pelo visconde de Fenouillèdes, Udalgério, a seu Vassalo Adalberto de Camélas em $1142^{15}$. O último caso, que nós retomaremos adiante, concerne a Guilherme Reig, o primeiro profissional roussillonnais qualificado de notarius.

Era muito raro que os escreventes eclesiásticos tomassem o cuidado de indicar em sua subscrição o nome do estabelecimento religioso, capítulo, mosteiro, priorado ou comendadoria, ao qual eles estavam ligados. Três profissionais fazem exceção a esta regra: Arnaldo, diácono e monge do mosteiro beneditino de Santo André, em 1172 ${ }^{16}$; Arnaldo, diácono, depois padre, da comendadoria templária do Masdéu ${ }^{17}$ - sobre dezenove registros instrumentados de 1177 a 1195 , ele indicou somente uma vez seu pertencimento a esta casa ${ }^{18}$ - e Raimundo, padre e cônego do priorado agostiniano de Santa Maria do Campo, em $1183^{19}$. 
No condado de Roussillon, parte oriental da diocese de Elne, é, portanto, no seio do clero das igrejas paroquiais que se recrutava, no século XII, o maior contingente de escreventes dos registros privados. Este fato não oculta a importância ainda bem marcada dos letrados oriundos dos capítulos e dos $\operatorname{mosteiros}^{20}$. A generalização do notariado público no século seguinte encerraria a hegemonia da Igreja sobre a escritura diplomática.

\section{OS PRIMEIROS PASSOS DO NOTARIADO PÚBLICO EM ROUSSILLON}

Vimos que os escreventes roussillonnais do século XII, muito raramente, precisavam sua função de escrevente, a maior parte dos profissionais se limitava a indicar seu nome e seu ranque na clericatura antes de traçar sua chancela ${ }^{21}$. Por consequente, a aparição nas fórmulas de subscrição de qualificações novas tais como notarius ou scriptor publicus deve ser compreendia como a manifestação de uma mudança significativa das práticas do escrito diplomático ${ }^{22}$.

Fato particularmente notável, nas cartas roussillonnaises, encontram-se estas duas designações que apareceram pela primeira vez de maneira simultânea no escatocolo de um registro do mês de fevereiro de 1184. Trata-se da venda de um manso situado na paróquia de Santo André de São Féliu de Avall, feita por Bernardo de São Féliu e sua esposa Catalana a Gausberto, visconde de Castelnou. A fórmula de validação nos informa que Bernardo Berengário, escrevente público, escreveu a ata como substituto do notário Guilherme Reig ${ }^{23}$. Se Guilherme Reig não figura em nenhum documento anterior, não é o mesmo para Bernardo Berengário, que já exercia sua arte na capital do Roussillon três anos antes. Entre janeiro e dezembro de 1181, ele redigia, de fato, muitos registros, na parte inferior dos quais ele indicava sua qualidade de diácono ${ }^{24}$. Após isso, ele não fez mais menção a seu pertencimento à clericatura. No curso dos anos 1184-1187, o escrevente público Bernardo Berengário assim instrumentou muitos registros para o notário Guilherme Reig. Parece que Bernardo Berengário, posteriormente, se emancipou e agiu novamente por sua própria autoridade, pois o encontramos, em novembro de 1187, subscrevendo um registro que, ditado por ele, o diácono Pedro escrevera ${ }^{25}$. Este documento é notável, pois se trata do primeiro instrumento inserido no repertório de nossa documentação sobre o qual figuram juntos as subscrições e as chancelas do escrevente e do redator. Esta dupla subscrição, cuja prática se sistematizaria em seguida, tornava-se necessária quando o escrevente do registro, seja ele aprendiz ou substituto, não era o depositário da fides publica. De fato, somente a subscrição do escrevente 
público ou do notário, associada ou traçada com sua chancela, tinha o poder de conferir autenticidade ao documento ${ }^{26}$. Foi também a partir do final do século XII que as chancelas dos escreventes começaram a se singularizar, cada profissional tendo, doravante, de inserir em suas fórmulas de subscrição um pictograma específico e distintivo ${ }^{27}$.

Em seguida, de 1189 até o mês de agosto de 1195, foi outro escrevente público, Pedro de Vernet, padre do Vernet, paróquia situada no norte de Perpignan, que instrumentava pelo notário Guilherme Reig ${ }^{28}$. O primeiro notário perpignanais desapareceu em seguida e Pedro de Vernet lhe sucedia, conservando o qualificativo de scriptor publicus. A partir do mês de janeiro de 1196, este último subscrevia ex officio registros cuja leitura era confiada a um escrevente chamado Pôncio de Bajoles ${ }^{29}$. Notar-se-á que os sobrenomes destes primeiros escreventes públicos de Perpignan indicam um recrutamento local, sendo o Vernet e o Bajoles dois vilarejos limítrofes da capital do condado de Roussillon.

A aparição concomitante dos vocábulos notarius e scriptor publicus, além da sistematização subsequente da dupla redator/escrevente, nos registros privados instrumentados em Perpignan, constituem indícios fortes que testemunham uma mudança importante intervindo no enquadramento jurídico da prática escriturária. Esta inovação, que se colocaria, portanto, em janeiro de 1184, ou pouco tempo antes, somente poderia ser a instituição do ofício público nesta vila comercial em pleno crescimento.

Logo, é bem verossímil atribuir a instauração do notariado público em Perpignan ao reinado de Afonso II. A ata fundadora desapareceu infelizmente e a documentação não conserva qualquer documento de criação de notário se referindo aos primeiros tempos da escrivania. Encontra-se, por outro lado, nos arquivos regionais, dois documentos que permitem conceber uma ideia bem precisa da maneira que se procedia no assunto. O primeiro concerne à instituição do tabelionato público na cidade languedociana de Béziers, em $1178^{30}$, e o segundo se remete à concessão do notariado da vila catalã de Vilafranca del Penedès em 1188 (CARRERAS Y CANDI, 1913, p. 773-774).

Estabelecidos com dez anos de intervalo, os dois documentos apresentam imediatamente uma similitude diplomática evidente, pois eles tomam o formato do contrato de acapte, ou seja, o instituto catalão protótipo de nosso arrendamento enfiteutico. A autoridade instituída, respectivamente o bispo de Béziers e o rei de Aragão, aí concedia ao profissional receptor, a título vitalício ou perpétuo, o monopólio do exercício do ofício público, qualificado de tabellionatum em Béziers, de notaria ou scribania em Vilafranca, em um território com contornos jurídicos definidos no registro, que eram aquele da paróquia ou da vila. É premente salientar que, nos dois casos, as autoridades exigiam um mesmo direito de R. Fac. Dir. UFG, v. 39, n.2, p. 43 - 86, jul. / dez. 2015 


\section{PRELÚDIO A HISTÓRIA DO NOTARIADO PÚBLICO EM PERPIGNAN E NO}

CONDADO DE ROUSSILLON (1184-1340)

entrada de 100 soldos, mas se este montante era expresso em moeda de Melgueil no registro relativo a Béziers, aquele concernente a Vilafranca não precisava a unidade de conta, o que se supõem ser a moeda de Barcelona. Isso não muda nada, pois estas duas moedas tinham um valor idêntico. Uma diferença importante distingue, todavia, os dois contratos: o bispo de Béziers exigia que o tabelião lhe desse, a cada ano, seis libras de pimenta, pro usatico, no dia de Natal; por sua parte, o rei Afonso II não reclamava qualquer censo anual do clérigo da igreja de Vilafranca que ele investia no ofício público. A condição religiosa do beneficiário poderia explicar esta liberdade principesca.

A aparição do notariado público em Perpignan se inscrevia de maneira perfeitamente coerente em um contexto cronológico, o último quarto do século XII, que assistiu à eclosão desta instituição nas principais cidades de Provença, Languedoc e Catalunha $^{31}$. É o caso de Saint-Gilles $(1171)^{32}$, Nîmes $(1185)^{33}$, Montpellier (cerca de 1140) ${ }^{34}$, Agde $(1175)^{35}$, Narbonne $(1177)^{36}$, Béziers (1178), Toulouse (1179) ${ }^{37}$, Girona $(1187)^{38}$, Vilafranca del Penedès (1188), Tarragone e Cervera. O ofício público apareceu, igualmente de modo precoce, nas vilas de feira, à imagem de Montagnac, entre Béziers e Montpellier, onde um publicus tabellionus exercia o ofício desde 1191 (SAÏDI, 2005-2006). Villefranchede-Conflent dispunha de um notário público, ao menos, desde 1203. Como em Perpignan, a jurisdição da capital do Conflent relevava diretamente da autoridade da Coroa de Aragão. Este fato é suficiente para explicar a implantação precoce da instituição nesta vila mercantil fundada pelo conde de Cerdagne em $1095^{39}$.

\section{ESCREVENTES PÚBLICOS E CÔNEGOS}

O notariado meridional estava na origem de um fenômeno urbano que ganhava, em primeiro lugar, as cidades episcopais e as principais vilas mercantis, antes de se difundir, por contágio, nas vilas secundárias e nos castelos. Em Roussillon, como bem de outros países mediterrânicos, se observa que o ofício público se propagava de início nos meios canonicais.

Em Elne, o ofício público foi atestado pela primeira vez em abril de 1205, na pessoa de Sancho, que acumulava as funções de subdiácono, capiscol e escrevente público ${ }^{40}$. A função de mestre da escola catedral naturalmente predispunha seu ocupante a assumir a redação dos contratos passados na cidade episcopal ${ }^{41}$. Em novembro de 1208, o mestre escola Sancho delegava sua autoridade ao subdiácono Jaime, este último opunha sua própria chancela na parte de baixo do documento que ele redigiu ${ }^{42}$. Em 1214, ao se tornar diácono, 
Jaime redigiu um documento de venda, sempre sob a autoridade do capiscol da Igreja de Elne $^{43}$. Nestes dois registros, se constata a ausência de subscrição do detentor da fides publica. Este fato parece significar que a menção da delegação de poder, indicada na fórmula de autenticação pelo advérbio latino vice, era suficiente para conferir força comprobatória ao instrumento público redigido pelo escrevente que operava sob a autoridade moral do mestre escola do qual ele era, certamente, um dos alunos os mais devotados. Jaime devia, também, suceder a seu mestre na cabeça da escola catedral. Em agosto de 1220, ele instrumentava a venda feita aos templários de Masdéu, mas ele não fazia qualquer menção, em sua subscrição, de sua qualidade de escrevente público ${ }^{44}$.

O magistério de Jaime foi assaz curto. Seu sucessor, João de Canohès, apareceu pela primeira vez em janeiro de 1217 entre as testemunhas de uma venda de bens situados na paróquia de Santo Estêvão de Ponteilla feita ao irmão Balaguer, comendador de Masdéu ${ }^{45}$. Ele construiu uma carreira clerical, pois ele portava o título de subdiácono. João de Canohès reapareceria seis anos mais tarde, em 28 de agosto 1223, como redator do registro de venda de um manso efetuada por um cônego da catedral de Elne. Se seu grau na clericatura não evoluiu, sua subscrição precisava, por outro lado, seu pertencimento ao clero do capítulo de Elne, onde ele exerceu, por sua vez, o ofício de capiscol e manteve a qualidade de escrevente público $^{46}$. Nós o reencontramos de novo na condição de redator em 1229. Sua fórmula de corroboração se tornou mais lacônica, ele se limitava simplesmente a indicar sua dignidade de capiscol, sem mencionar sua qualidade de escrevente público ${ }^{47}$. Ele conservou este uso até o fim de sua carreira, que ocorreu por volta de $1240^{48}$. No total, sobre seis registros escritos por João de Canohès, uma única, a mais antiga, mencionava sua qualidade de oficial público. Aquilo demonstra claramente que medir a progressão do notariado público em termos das subscrições somente constitui, em certos casos, um paliativo. A fiabilidade estatística da informação assim coletada está bem longe de ser absoluta. Quantos foram, na realidade, aqueles, a instar dos capiscoles de Elne, que omitiram sua qualidade de depositários da fides publica em suas fórmulas de corroboração?

Os capiscoles encarregados da instrução dos padres e dos clérigos no seio do capítulo catedral, necessariamente, deviam ser solidamente instruídos, notadamente em gramática latina e em retórica ${ }^{49}$. Nós lamentamos não dispor de qualquer informação sobre a natureza do ensino que era ministrado nos seio do capítulo de Elne nesta época. Parece que a dignidade de capiscol junto ao capítulo de Elne desapareceu com Joan de Canohès. Foram, todavia, membros do clero da catedral que continuaram, em seguia, a exercer o ofício de scriptor publicus na cidade episcopal ${ }^{50}$. 
O notariado público de Perpignan conheceu também um período de estreita relação com o meio canonical, em especial aquele do capítulo colegial da igreja de São João, fundado em 1102. Nós vimos, anteriormente, que Pôncio de Bajoles iniciou sua carreira de profissional do escrito sob as ordens do padre e escrevente público Pedro de Vernet ${ }^{51}$. No dia 30 de janeiro de 1196, ele redigiu, ditado por seu mestre, o testamento de Vicente de Cabestany, o qual estipulava, notadamente, as doações piedosas em favor do hospital dos pobres de São João de Perpignan e da igreja de São João ${ }^{52}$. Após o desaparecimento de Pedro de Vernet, ocorrida em 1205, Pôncio de Bajoles obteve sua qualificação de escrevente público e prosseguiu sua carreia no estudo de Perpignan, seja se tratando de sua própria autoridade, seja, o mais frequentemente, instrumentando sob a autoridade de um confrade. Em setembro de 1207, ele expediu uma transação na qualidade de encarregado do escrevente público Berengário de La Grasse ${ }^{53}$. No dia 2 de fevereiro de 1210, Pôncio de Bajoles foi recebido como cônego da igreja de Saint-Jean de Perpignan pelo capelão do colegial, Pedro Gros. O ato solene foi redigido por Berengário Alamberto e trouxe a subscrição do escrevente público Berengário de La Grasse que, nesta única ocasião, nos revelou seu pertencimento ao capítulo $^{54}$. Nos registros instrumentados no curso desse mesmo ano, Pôncio de Bajoles teve a preocupação de mencionar seu novo estatuto, como, por exemplo, no escatocolo de uma doação feita aos templários do Masdéu em 26 de abril de $1210^{55}$. Ele renunciou, contudo, muito rapidamente a esta prática e, em março de 1211, ele expediu uma venda como substituto de Berengário de La Grasse, qualidade expressa pela locução vice gerens $^{56}$. No mesmo ano, esta responsabilidade de substituto foi confiada a Pedro Raimundo, que a exerceu até agosto de $1212^{57}$.

Encontra-se novamente Pôncio de Bajoles como vice-regente da escrivania de Perpignan de 1214 a 1216. Ao curso dos anos seguintes, muitos substitutos do regente Berengário de La Grasse se sucederam no estudo Perpignan. Uma hierarquização se operava, distinguindo o regente, os escreventes públicos que o substituíam para redigir e os aprendizes que escreviam sob o ditado do regente ou de um de seus encarregados. Assim, em outubro de 1217, o jovem Raimundo de Fourques redigiu um ato de venda sob o ditado de seu mestre, o padre e escrevente público Raimundo, o qual precisava, em sua subscrição, que ele agia na qualidade de substituto de Berengário de La Grasse ${ }^{58}$. Do mesmo modo, em 17 de janeiro de 1220, Bernardo Jugna fez escrever o testamento de Guilherme de Cabestany por seu aluno Bernardo Berriach ${ }^{59}$. 
Assiste-se, a partir de 1215, a um sensível aumento do número de profissionais do escrito atuando em Perpignan. Esta elevação dos efetivos foi acompanhada dos primeiros indícios manifestos de uma formação de jovens aprendizes no seio do estudo. São recenseados, assim, nove escreventes e aprendizes ao curso dos cinco últimos anos de regência de Berengário de La Grasse, que desapareceu da documentação após março de 1220. Foi Pôncio de Bajoles quem tomou então a direção do notariado de Perpignan. Esta sucessão se acompanhou cedo de uma novidade na maneira de formular as subscrições, pois, doravante, o regente indicava de qual autoridade ele tinha a fides publica. Trata-se, neste caso, de Nuno Sancho, senhor a título vitalício dos condados de Roussillon e de Cerdagne e, a este título, senhor da vila de Perpignan ${ }^{60}$.

A longa carreira de Pôncio de Bajoles terminou por volta do final de março de 1225, após, pelo menos, trinta anos de atividade, dos quais metade passada no seio do capítulo da igreja São João ${ }^{61}$. Insistir-se-á na discrição dos cônegos perpignanais que, por uma razão não elucidada, evitavam declarar seu estatuto religioso nas suas fórmulas de subscrição. Pôncio de Bajoles somente o fez nos meses que seguiram sua recepção; seu mestre, Berengário de La Grasse, somente declarou sua qualidade de cônego em um único registro das dezenas conservadas onde figuravam sua subscrição; nós vimos em qual circunstância.

Assinalar-se-á, enfim, a fórmula de corroboração de um ato datado de 16 de setembro de 1224, no qual, Pôncio de Bajoles declarou ter o estudo de Perpignan pelo senhor Nuno Sancho ${ }^{62}$. Seu interesse particular reside no fato de se tratar da mais antiga menção encontrada da palavra scribania na documentação roussillonnaise. Observa-se, aliás, que esta precisão era, muito raramente, expressa nas fórmulas de autenticação ao curso do período estudado: nós temos recenseado somente duas outras ocorrências nos registros feitos no estudo de Ille-sur-Têt, um em 1261 e o outro em $1303^{63}$.

Nos documentos catalães da Idade Média, era o vocábulo scribania, às vezes acompanhado do epíteto publica, o mais frequentemente utilizado para designar a instituição notarial desde seu advento ${ }^{64}$. Encontra-se regularmente associada à palavra notaria, que parece ter sido de um uso menos frequente ${ }^{65}$. Nas cartas, o genérico scribania designava, às vezes, o ofício público, o estudo propriamente dito e a alçada territorial submetida a sua jurisdição, a qual coincidia quase sempre com aquela da paróquia. Fora de Perpignan, nós temos encontrado a menção de scribania nos instrumentos que se reportavam à localidade de Thuir (1252) ${ }^{66}$, Villefranche-de-Conflent (1254) ${ }^{67}$, Ille-sur-Têt (1261), Céret (1321) ${ }^{68}$, Peyrestortes (1325) e Banyuls dels Aspres (1333). Convém, contudo, relativizar a impressão restrita proporcionada pelo pequeno número de localidades enumeradas aqui, salientando que R. Fac. Dir. UFG, v. 39, n.2, p. 43 - 86, jul. / dez. 2015 
este recenseamento resulta de um exame parcial dos arquivos conservados e que, por outro lado, nosso conhecimento é particularmente afetado pela perda particularmente deplorável da quase totalidade dos registros das diferentes administrações da Coroa de Mallorca que se remetiam aos condados de Roussillon e de Cerdagne. Nas cartas roussillonnaises dos séculos XIII e XIV, a palavra scribania foi igualmente empregada para designar as inclusões dos diferentes ofícios públicos e, especialmente, aqueles da corte do batlle de Perpignan e do vigário de Roussillon ou da corte de apelo ao palácio dos reis de Mallorca.

A contribuição dos cônegos à ascensão do notariado público no condado de Roussillon é igualmente atestada em Torreilles, importante castelo situado no plano litoral de Salanque, cujo senhorio era partilhado entre três co-senhores principais. O primeiro escrevente público de Torreilles, o préchantre Guilherme Fort, parece ter tomado o relevo do mestre de gramática, Arnaldo, já discutido anteriormente. Ainda que jamais fosse especificado nos documentos, o pertencimento destes dois personagens a colegial São Juliano de Torreilles não traz qualquer dúvida. Guilherme Fort apareceu pela primeira vez em 14 de fevereiro de 1207, dia em que ele instrumentou a venda feita por Guilherme Savaric ao senhor Raimundo de Castellrosselló de um pedaço de terra situado em Torreilles ${ }^{69}$. Cinco anos mais tarde, no dia 10 de março de 1212, ele redigiu a entrega feita por Beatriz, esposa do senhor Pedro de Torreilles, a Raimundo de Castellrosselló, outro cosenhor deste castelo, de seus direitos e ações sobre um pedaço de terra, mediante a soma de 50 soldos de moda de Barcelona. Ainda que formulada como uma ação espontânea, esta renúncia mostra-se, na realidade, resultar de uma arbitragem confiada ao bispo de Elne, Raimundo, e a outros bons homens, como o exprime o redator do registro em uma frase inserida no escatocolo, depois da subscrição das testemunhas ${ }^{70}$. Em 28 de outubro de 1216, sendo mestre da escola canonical, Guilherme Fort redigiu o documento pelo qual Guilherme Sallner de Torreilles se colocava sob a salvaguarda de Pôncio de Vernet, outro co-senhor do castelo de Torreilles ${ }^{71}$.

Os serviços do escrevente público Guilherme Fort eram manifestadamente apreciados por Raimundo de Castellrosselló que lhe confiou sistematicamente a redação de seus contratos concernentes a seu senhorio de Torreilles ${ }^{72}$. Conservam-se, assim, três arrendamentos em enfiteuse ou em usufruto concedidos por Raimundo de Castellrosselló em 24 de maio de 1212, em 5 de março de 1214 e em 27 de setembro de 1217 . O chartrier deste senhor encerrava igualmente um excepcional arrendamento ou bail en commende de dois mansos por uma duração de dois anos, passado o primeiro de março de 1219. Este registro trazia uma cláusula de garantia contra os riscos naturais e humanos, o que testemunha um 
bom nível dos conhecimentos jurídicos do erudito de Torreilles ${ }^{73}$. No dia 11 de março de 1222, Guilherme Fort instrumentou o reconhecimento feito por Raimundo Asemar, homem dependente do senhor Pôncio de Vernet. A última menção de Guilherme Fort figura na subscrição de um registro de 30 de março de 1226, instrumentado posteriormente por seu sucessor, Guilherme Fimaç, segundo as notas do capiscol, que, moribundo, não teve forças para se ocupar disso pessoalmente ${ }^{74}$. Convém relevar o grande interesse pela diplomática notarial desta evocação precoce de uma redação preparatória do documento sob a forma de uma nota que tinha, manifestadamente, valor autêntico.

A morte de Guilherme Fort marcou, aparentemente, o fim da fase canonical da história do notariado de Torreilles. Seu sucessor, o escrevente público Guilherme Firmaç, ativo até em 1241, nunca demonstrou manter qualquer laço com o clero ou com o capítulo. A similitude e o sincronismo deste fenômeno com o que se pode observar em Perpignan é, deste ponto de vista, notável: pode-se, sem muito risco, interpretá-lo como a manifestação de uma tendência a laicização do notariado após um período de transição assegurado pelos cônegos dos capítulos seculares, os quais tiveram um papel importante no estabelecimento do ofício público no curso dos primeiros decênios do século XIII ${ }^{75}$.

\section{PAPEIS E PROTOCOLOS}

Os Arquivos departamentais dos Pyrénées-Orientales conservam dezessete protocolos de notários perpignanais da segunda metade do século XIII. O mais antigo manual ou registro de breves do notariado de Perpignan cobre um período de atividade indo de maio a setembro de 1260, durante o qual o estudo foi regido pelo escrevente público Pedro Calvet. É notável que a série dos protocolos dos notários de Puigcerdà, capital do condado de Cerdagne, começou também em 1260 (BOSOM i ISERN \& GALCERAN i VIGUÉ, 1983, p. 310). Seria enganoso deduzir desta simples coincidência cronológica que é somente a partir deste momento que os notariados dos condados norte-catalães adotaram o procedimento de assentamento sistemático de suas notas nos registros. Nós evocamos precedentemente a menção ao uso de notas em Torreilles, em 1226. Se se apoia sobre a data dos mais antigos protocolos notariados conservados nas vilas secundárias da Catalunha central, como Vic (1221, 1230-1233) (GINEBRA i MOLINS, 2001, p. 7-22; 1998), Manresa (1222-1223) (TORRAS i SERRA, MASATS i SURIÑACH, VALDENEBRO i MANRIQUE \& VIRÓS i PUJOLÀ, 1993, p. 12-13), Alcover (1228-1229) (PONS I GURI et alii, 1989, p. 161-294), Siurana (1229-1239) (RAMON i VINYES \& FUENTES i GASÓ, 1987) e Terrassa (1237R. Fac. Dir. UFG, v. 39, n.2, p. 43 - 86, jul. / dez. 2015 
1242) (PUIG I USTRELL, 1992), ou sobre o caso excepcional da cidade de Mallorca que conservou seus protocolos desde a instituição do notariado que se seguiu a conquista da ilha pelo rei Jaime I, em 1230 (PÉREZ MARTINEZ, 1977), parece que a generalização desta prática remonta ao decênio 1220-1230, ou seja, com um atraso de uma dezena de anos em relação às grandes cidades do norte e do centro da Itália ${ }^{76}$.

Como foi observado muitas vezes, todos os antigos protocolos notariados conservados nos arquivos catalães foram redigidos em papel (CARRERAS Y CANDI, 1913, p. 761; FERRER I MALLOL, 1974, p 55-56; TRÉTON, 2006, p. 61-62) ${ }^{77}$. Aquilo nos leva a presumir que nos territórios da Confederação catalã-aragonesa, a inovação da prática notarial em assentar sistematicamente as notas ou breves em registros foi condicionada pela difusão do novo suporte da escrita. O uso administrativo do papel foi atestado na chancelaria do rei Afonso I de Aragão desde 1195 (BISSON, 1989, note 57 p. 196). A difusão crescente do papel, observável a partir do segundo terço do século XIII, se explica em grande parte por seu custo de produção, incomparavelmente mais barata que a do pergaminho, que constituía, anteriormente, o único suporte utilizado para as escrituras diplomáticas ${ }^{78}$.

Esta inovação, suspeita-se, teve inumeráveis consequências. Sobre o plano social, pode-se considerar, sem muito risco de extrapolação, que o uso do papel contribuiu de maneira decisiva na difusão do notariado nos campos. Ele favoreceu, ao mesmo tempo, a democratização e a sistematização do recurso ao escrito para a formalização dos contratos privados. Mediante alguns denários, custo do registro da minuta, uma grande parte da população pôde, então, obter a mediação do oficial público, depositário da fides publica. Contudo, é necessário reconhecer que as modalidades desta mutação se revelam particularmente difíceis de esclarecer em razão, notadamente, da carência documental relativa a este período de inflexão de nossa história. A leitura dos protocolos mostra, de maneira patente, que foram os que manejavam o dinheiro, credores judeus e cristãos, mercadores e artesãos, que se impuseram de imediato como os principais utilizadores do novo sistema ${ }^{79}$. Ao formalizá-los, o notário contribuía para o enquadramento jurídico das práticas econômicas, das quais ele se tornou rapidamente a engrenagem incontornável.

Estas mudanças foram acompanhadas também de uma modificação significativa das práticas escriturarias. Os paleógrafos, durante muito tempo, observaram a transformação notável que afetou a escritura nos países do Ocidente cristão ao curso deste período crucial (STIENNON, 1991, p. 129). Confrontados com a necessidade de responder a uma demanda que crescia sem cessar, os escreventes abandonaram a bela escritura carolíngia em proveito da 
cursiva gótica, escrita mais ligada e mais rápida para executar, elaborada na segunda metade do século XII pelos escreventes da chancelaria pontifical.

\section{O PROCESSO DE LAICIZAÇÃO DO NOTARIADO}

Foi nos idos de 1210-1220 que a instituição notarial começou a se difundir progressivamente nos campos, sendo o ofício público exercido, em seus inícios, muito majoritariamente pelos membros do clero. O exame dos registros roussillonnais aponta um declínio sensível desta predominância eclesiástica no curso da segunda metade do século XIII. As autoridades logo procuraram afastar os membros do clero dos ofícios públicos, particularmente do notariado. Assim, em 26 de novembro de 1211, o papa Inocêncio III, em sua carta apostólica, "Sicut te accepimus", ordenou ao bispo de Ascoli a interditar o notariado aos clérigos investidos das ordens sagradas: padres, diáconos e subdiáconos ${ }^{80}$. A motivação desta prescrição se explicava por que os clérigos escapavam da justiça temporal e, por esta razão, não podiam ser punidos por juízes seculares. Esta impunidade privava, por consequência, a autoridade garantidora da fides publica de todo meio legal de reprimir um clérigo culpado de exercer atividades fraudulentas no exercício de seu ofício público. Aquilo gerava, evidentemente, um grave problema de ordem moral e jurídica ${ }^{81}$.

Este combate pela laicização dos ofícios públicos constituiu uma das prioridades do reinado do conde-rei Jaime I. Nas cortes de Huesca, celebradas em 1247, este monarca e a assembleia reuniram os representantes do clero, da aristocracia e da burguesia da Coroa de Aragão, interditando o exercício do ofício de notário público aos membros do clero (CARRERAS Y CANDI, 1913, p. 755). Em 31 de outubro do mesmo ano, em Valencia, o Conquistador retomou esta prescrição em uma série de estatutos destinados à cidade e ao reino de Mallorca. Ele ordenava que cada clérigo tonsurado ou professo nas ordens sagradas não pudesse ser instituído notário público, nem fazer instrumentos públicos, testamentos, contratos de casamento ou outros tipos de registros e que não se atribuíssem qualquer autenticidade jurídica a tais instrumentos que seriam desprovidos de valor probatório. Ele ordenava, por outro lado, que aquele que se fizesse clérigo ou portasse a tonsura após ter assumido o cargo de tabelião, fosse privado de seu ofício. Jaime I prescrevia, em seguida, as condições requeridas para a investidura do notário: o impetrante deveria ser domiciliado na vila onde ambicionasse exercer o ofício ou na sua periferia e devia ter 25 anos de idade. Aquele que cumprisse as condições prévias era apresentado ao vigário, em presença do qual ele era submetido a um exame por dois experts em direito, a fim de avaliar seus R. Fac. Dir. UFG, v. 39, n.2, p. 43 - 86, jul. / dez. 2015 


\section{PRELÚDIO A HISTÓRIA DO NOTARIADO PÚBLICO EM PERPIGNAN E NO}

CONDADO DE ROUSSILLON (1184-1340)

conhecimentos; se ele fosse julgado competente para redigir instrumentos, ele seria investido e deveria jurar exercer seu oficio fiel e lealmente ${ }^{82}$.

Estas prescrições, estendidas ao conjunto dos territórios da confederação catalãaragonesa, foram rigorosamente aplicadas nas localidades que relevavam diretamente da jurisdição real. Por outro lado, aponta-se que elas somente foram suficientemente aplicadas nas paróquias onde o ofício público estava submetido ao controle da autoridade episcopal ${ }^{83}$. Observa-se, aliás, que no assunto, o rei de Aragão não hesitava em transgredir suas próprias leis, quando aquilo se revelava útil ou necessário. Assim, em 7 de setembro de 1257, Jaime I concedeu, em caráter vitalício, a Bernardo Alegret, acolito, o notariado da localidade aragonesa de Avosca e de seu território, com a faculdade de escrever e de redigir os instrumentos, os registros, as atestações, os testamentos e todas as outras escrituras públicas. Ele lhe concedia o direito de exercer o ofício, a despeito de seu pertencimento ao clero, e não obstante os fueros de Aragão (HUICI MIRANDA \&CABANES PECOURT, vol. III, 1978, doc. $\left.n^{\circ} .773\right)$.

\section{A ATRIBUIÇÃO DA FIDES PUBLICA}

Até o último terço do século XIII, a prerrogativa de criar notários no condado de Roussillon parece ter sido partilhada entre os príncipes da casa de Barcelona e os bispos de Elne, uma sorte de modus vivendi instalado que, de fato, sustentava uma situação, bem difícil de discernir.

A partir de 1220, os profissionais perpignanais começaram a indicar de qual autoridade eles tinham a fides publica. No início, a expressão desta delegação de poder era geralmente expressa pelo verbo mandare, desde muito tempo em uso na chancelaria real. Nós temos já evocado o caso de Pôncio de Bajoles que, a partir do momento em que tomava a regência da escrivania de Perpignan, indicava em sua subscrição que dispunha do poder de autenticar os registros pelo mandado que lhe tinha feito o senhor Nuno Sancho. Desde então, esta prática se tornou sistemática no seio do notariado perpignanais ${ }^{84}$. É necessário, todavia, esperar os anos 1240 para que a expressão da auctoritas se generalizasse nas subscrições dos notários roussillonnais. Assim, em abril de 1238, Bernarado Amalric, sacristão da igreja de Orle e escrevente público, precisou que ele subscrevia e opunha sua chancela pela autoridade que o bispo de Elne lhe havia conferido ${ }^{85}$. No ano seguinte, seus confrades, Jaime Pelegrí, padre e sacristão de Malloles e Pedro de Maureillas, padre de Castellrosselló, adotaram 
igualmente este uso ${ }^{86}$. A generalização desta nova prática traduz uma evolução na organização do notariado no condado de Roussillon ligada, provavelmente, a uma regulamentação mais rigorosa do ofício público.

A ascensão de Jaime I a cabeça do condado de Roussillon, em janeiro de 1242, se manifestou, sobre o plano diplomático, por uma nova modificação da titulação dos notários perpignanais. Pedro Calvet, que subscreveu o testamento de Nuno Sancho, em 17 de dezembro de 1241, na qualidade de escrevente público sob o mandado deste senhor ${ }^{87}$, reaparecia no mês de março de 1242, indicando o nome da vila onde ele exercia seu oficio. Por outro lado, ele não mais mencionava o nome da autoridade de tutela ${ }^{88}$. Esta mudança de prática já fora atestada no mês de fevereiro de 1242, com o notário Raimundo Carles ${ }^{89}$. Seus sucessores manteriam este uso ao longo do século seguinte.

O retorno do condado a administração direta da Coroa de Aragão e a politica de Jaime I, visando recuperar os direitos regalianos, suscitaram tensões com as principais potências temporais que tinham aproveitado as desordens dos decênios precedentes para se imiscuir, às vezes para se substituir completamente, a uma autoridade pública enfraquecida em vários níveis. Até então, em razão da antiga hegemonia clerical sobre o notariado, o bispo de Elne exercia sua autoridade sobre quase todas as localidades da diocese, além de algumas vilas reais: Perpignan, Claira ${ }^{90}$, Collioure ${ }^{91}$, Salses $^{92}$ e $^{\text {Thuirr }}{ }^{93}$.

Em 5 de janeiro de 1270, ao curso de uma assembleia solene reunida na sala capitular do convento dos Frades Pregadores de Perpignan, o arcebispo de Narbonne, Maurin, e os abades de São Paulo de Narbonne e de Fontfroide arbitraram sobre muitas questões litigiosas opondo o infante Jaime, herdeiro do reino de Mallorca, do senhorio de Montpellier e dos condados do norte catalão, ex oficio, como tenente de seu pai, de um lado, e o bispo de Elne, de outro ${ }^{94}$. Um dos motivos da discórdia que opunha estes dois partidos era a investidura dos notários na diocese de Elne. Após ter deliberado sobre o assunto, os árbitros decidiram que o rei e o infante teriam, doravante, a instituição dos notários públicos, clérigos ou laicos, nas terras relevando de seu domínio e o bispo, nas outras localidades da diocese. Quanto aos notários já instituídos pelo bispo nas terras reais, eles deveriam conservar seu ofício, em caráter vitalício, com o acordo do infante, mas eles estariam, doravante, submetidos à autoridade deste último. Consequentemente, eles deveriam estabelecer seus registros sob a autoridade do rei e do infante e lhes pagar o censo que eles deviam, anteriormente, ao bispo ${ }^{95}$. Esta arbitragem foi copiada, por volta de 1300, no Livro dos costumes do vicariato de Roussillon, o que significa que em suas respectivas matérias, estes 


\section{PRELÚDIO A HISTÓRIA DO NOTARIADO PÚBLICO EM PERPIGNAN E NO}

CONDADO DE ROUSSILLON (1184-1340)

estatutos foram, desde então, observados como as leis consuetudinárias em vigor nesta jurisdição.

A documentação não nos permite saber quais localidades reais tinham feito parte das intromissões episcopais. Entrementes, nos casos de Ille-sur-Têt e de Prats, elas são visíveis, pois uma mudança da autoridade sobreveio nestas localidades após a arbitragem de $1270^{96}$. É possível, tendo em mente esta data, que houvesse lugar para aproximar as reivindicações do infante Jaime de seu projeto de aquisição do patrimônio da poderosa linhagem roussillonnais dos senhores de Vernet, especialmente, os importantes castelos de Torreilles, Millas e Tautavel. De fato, no dia 18 de janeiro de 1270, após somente treze dias à arbitragem de Perpignan, o herdeiro do reino de Mallorca se encontrava em Castelló d'Empúries, a fim de negociar a transação com o conde Pôncio Hugo III, na ocasião moribundo, e com seu filho, Hugo. Neste dia, o infante abandonou todas as pretensões que ele tinha engajado contra o conde de Empúries e os habitantes de Millas, Torreilles e de Laroque, em razão de uma ruptura da Paz e da Trégua ${ }^{97}$. No dia 5 de fevereiro, o irmão Raimundo Roger, monge e sacristão de Santa Maria de Roses e irmão Arnaldo Piquer, tenente do prior dos Frades Pregadores de Perpignan, reconheceram que o herdeiro da coroa de Mallorca pagou 3400 soldos de moeda de Melgueil aos executores testamentários do defunto conde de Empúries pela compra do castelo de Tautave ${ }^{98}$. No dia 4 de outubro de 1271 , o jovem conde, Hugo V, prometeu ao infante Jaime que lhe venderia e lhe entregaria o castelo e a vila de Millas pelo preço de 40000 soldos de moeda de Melgueil, assim como o castelo e a vila de Torreilles por 30000 soldos. Conforme os estatutos de janeiro de 1270, a instituição notarial do castelo de Torreilles, que relevava até então do bispo de Elne ${ }^{99}$, se tornava, em seguida, uma prerrogativa do conde-rei ${ }^{100}$.

Ao curso da primeira metade do século XIV, o bispo de Elne, sem dúvida para terminar com suas reivindicações, entregava em feudo a diversos senhores o poder de instituir os notários nas localidades submetidas a sua jurisdição. Assim, no dia 19 de abril de 1325, o bispo Berengário Batlle entregou, em feudo, ao damoiseau Oton de Peyrestortes a escrivania de Peyrestortes, com a faculdade de instituir e depor os notários, assim como a de vender ou arrendar este ofício. Então, foi estipulado que o notário instituído deveria prometer ao bispo, sob juramento, que ele exerceria seu ofício com toda probidade. Ele deveria instrumentar sob a autoridade do bispo e subscrever utilizando a formula seguinte: “Eu, notário público de Peyrestortes, pelo honorável Oton de Peyrestortes e pela autoridade do bispo, escrevi e subscrevi esta carta e tenho feito esta chancela"; a escolha da chancela sendo deixada à 
discrição do profissional. Em reconhecimento deste feudo, foi previsto que o senhor de Peyrestortes daria, ao bispo e a seus sucessores, a cada ano, uma libra de cera no dia de Natal e o foriscape em caso de alienação. Segundo o rito consagrado, o senhor fez, em seguida, homenagem ao bispo e lhe jurou fidelidade.

Outro exemplo desta delegação de autoridade pelo direito feudal nos foi dado por um ato datado de 10 de abril de 1333, cujo dispositivo reproduzia, segundo algumas adaptações, o formulário precedente. De fato, neste dia, Dalmau de Banyuls, senhor de Banyuls-des-Aspres, reconhecia ter em feudo pelo bispo de Elne, irmão Gui de Terrena, a escrivania de seu castelo de Banyuls, com a faculdade de instituir e de depor os notários, assim como de vender ou de arrendar a dita escrivania. O notário instituído deveria prestar juramento ao bipo de exercer seu oficio em toda probidade. Ele deveria instrumentar sob a autoridade episcopal e subscrever assim: “Eu, notário púbico de Banyuls-dels-Aspres, pelo honorável Dalmau de Banyuls e pela autoridade do bispo, escrevi e subscrevi esta carta e tenho feito esta chancela", a escolha da chancela sendo, ainda, deixada à discrição do profissional. Em reconhecimento deste feudo, era previsto que Dalmau daria ao bispo uma libra de cera a cada ano, no dia de natal, e o foriscape em caso de alienação; em seguida, seus herdeiros deveriam dar, além disso, um par de perdizes. O dispositivo era completado com a notificação da homenagem e do juramento de fidelidade feitos ao prelado.

A fim de sintetizar as informações reunidas no curso deste primeiro estágio de nossas pesquisas, nós temos estabelecido o seguinte quadro, no qual está indicada, para cada localidade documentada, a autoridade que dispunha do poder de instituir os notários. Este esboço de geografia notarial do condado de Roussillon e do Vallespir evidenciou que certos mosteiros e senhores laicos depunham igualmente do poder de criar notários nas localidades que eles detinham a jurisdição ${ }^{101}$. Assim, por exemplo, os beneditinos da abadia de La Grasse, em Narbonnais, tinham a autoridade sobre os vilarejos de Pézilla-la-Rivière, Corneilla-de-laRivière e de Las Fonts. 
PRELÚDIO A HISTÓRIA DO NOTARIADO PÚBLICO EM PERPIGNAN E NO

CONDADO DE ROUSSILLON (1184-1340)

Nomenclatura (provisória) do notariado em Roussillon e Vallespir por volta de 1300

\begin{tabular}{|c|c|}
\hline $\begin{array}{c}\text { Localidades dispondo do notariado } \\
\text { público }\end{array}$ & Autoridades Mandatárias \\
\hline Argelès & $\mathrm{O}$ conde-rei \\
\hline Arles & $\mathrm{O}$ abade de Arles \\
\hline Bages & O bispo de Elne \\
\hline Bajoles, & O bispo de Elne \\
\hline Banyuls dels Aspres & O bispo de Elne/ o senhor de Banyuls (feudo) \\
\hline La Bastide & O senhor de Corsavy \\
\hline Belpuig & O bispo de Elne \\
\hline Brouilla & O bispo de Elne \\
\hline Cabestany & O bispo de Elne \\
\hline Calce & $\mathrm{O}$ conde-rei \\
\hline Calmeilles & O bispo de Elne \\
\hline Canet & O bispo de Elne \\
\hline Castelnou & O bispo de Elne \\
\hline Castell Rosselló & O bispo de Elne \\
\hline Céret & O bispo de Elne \\
\hline Claira & O conde-rei \\
\hline Corneilla de la Rivière & O abade de Lagrasse \\
\hline Corneilla del Vercol & O bispo de Elne \\
\hline Corsavy & O senhor de Corsavy \\
\hline Elne & O bispo de Elne \\
\hline Espira de l'Agli & Le prieur de Espira \\
\hline Las Fonts & O abade de Lagrasse \\
\hline Ille-sur-Tet & $\begin{array}{l}\text { O bispo de Elne/ o senhor de Fenouillet } \\
\text { (feudo) }\end{array}$ \\
\hline Malloles & O bispo de Elne \\
\hline Maureillas & $\mathrm{O}$ conde-rei \\
\hline Millas & $\mathrm{O}$ conde-rei \\
\hline Mollet (Montferrer) & O bispo de Elne \\
\hline Nyls & O bispo de Elne \\
\hline Oms & O bispo de Elne \\
\hline Ortaffa & O bispo de Elne \\
\hline Palau [del Vidre] & O bispo de Elne \\
\hline Passa & O bispo de Elne \\
\hline Perpignan & O conde-rei \\
\hline Peyrestortes & $\begin{array}{l}\text { O bispo de Elne/ o senhor de Peyrestortes } \\
\text { (feudo) }\end{array}$ \\
\hline Pezilla-la-Rivière & $\mathrm{O}$ abade de Lagrasse \\
\hline Ponteilla & O bispo de Elne \\
\hline Prats (la ville et la vall) & $\mathrm{O}$ conde-rei \\
\hline Saint-Féliu d'Amont et d'Avall & O bispo de Elne \\
\hline Saint-Hippoyte & O bispo de Elne \\
\hline Saint-Laurent de la Salanque & $\mathrm{O}$ conde-rei \\
\hline
\end{tabular}


Rodrigue Tréton

\begin{tabular}{|c|c|}
\hline Salses & O conde-rei \\
\hline Le Soler & O bispo de Elne \\
\hline Tatzo d'Avall & O bispo de Elne \\
\hline Tautavel & O conde-rei \\
\hline Terrats & O bispo de Elne \\
\hline Thuir & O conde-rei \\
\hline Torreilles & O conde-rei \\
\hline Tresserre & O bispo de Elne \\
\hline Trouillas & O bispo de Elne \\
\hline Vilarnau & O bispo de Elne \\
\hline Villeneuve-de-la-Raho & O bispo de Elne \\
\hline
\end{tabular}

\section{A ORGANIZAÇÃO DO NOTARIADO PERPIGNANAIS DE MEADOS DO SÉCULO XIII ATÉ A SUPRESSÃO DO REINO DE MALLORCA}

Em Perpignan, a necessidade de se adaptar às importantes metamorfoses estruturais e conjecturais de uma vila em plena expansão constrangeram as autoridades a engajar uma série de reformas pragmáticas do oficio público. Mas vejamos, de início, o que sabemos sobre o funcionamento desta intuição.

Atualmente, para o Roussillon, nós somente encontramos dois registros de criação de notários para o conjunto do século XIII. Procedendo dos registros da Chancelaria do rei Jaime I, estes contratos concernem, todos os dois, à escrivania de Perpignan e adotam uma forma diplomática muito próxima das concessões protótipas do final do século XII descritas no início deste artigo.

No primeiro, datado de 8 de janeiro de 1258, o rei de Aragão concedia a Pedro Calvet, em caráter vitalício, toda a escrivania de Perpignan e o instituía notário público nesta vila, de sorte que ele e aquele ou aqueles que ele estabelecesse em seu lugar escreveriam e elaborariam todos os registros públicos que seriam assentados na capital do condado de Roussillon. O rei instituiu que todos os documentos que Pedro Calvet redigisse, quaisquer que fossem, obtivessem, em perpetuidade, força probatória em juízo ou em outra ocasião. Ele ordenou ao batlle ${ }^{102}$, aos bons homens ${ }^{103}$ e a toda universidade ${ }^{104}$ de Perpignan que eles o recebessem como seu único escrevente público e aqueles que ele estabelecesse em seu lugar só poderiam fazer seus registros com ele. Por esta concessão, o rei reconhecia ter recebido 500 soldos de moeda de Melgueil.

Esta investidura veio tardiamente na carreira de Pedro Calvet. Ele tinha, de fato, iniciado sue cursus trinta anos antes, junto ao estudo de Perpignan: ele redigia na qualidade de substituto de Pedro de Riu, de 1228 a $1233^{105}$. Ao curso deste período, no dia 17 de março de 
1230, Pedro Calvet redigiu e subscreveu sozinho, na qualidade de scriptor publicus, uma importante troca de patrimônios concluída entre os templários e os hospitalários de São João de Jerusalém $^{106}$. Ele sucedera a Pedro de Riu em junho de 1234 e, como seu predecessor, indicava ter recebido a investidura de Nuno Sancho, senhor dos condados de Roussillon e de Cerdagne $^{107}$. Após a morte deste último, ocorrida no mês de janeiro de 1242, Pedro Calvet trocava sua titulação. Sua fórmula de corroboração se enriquecia então da indicação do lugar onde ele exercia seu ofício, mas ela não fazia mais referencia a autoridade de tutela ${ }^{108}$. Posteriormente, ele conservou este costume, até sua morte, que ocorreu, provavelmente, no início do verão de 1265 .

O estudo prosopográfico evidenciou que a investidura da regência da scribania de Perpignan outorgada pelo conde-rei a Pedro Calvet, no começo do ano 1258, marcou, de fato, o retorno daquele a cabeça do notariado perpignanais após um pequeno eclipse de seis meses, durante os quais o escrevente público Guilherme Aimeric tinha tomado à frente do ofício ${ }^{109}$. Nós ignoramos quais razões tinham constrangido Pedro Calvet a deixar a escrivania nesse semestre; nós temos, por outro lado, a certeza de que ele retomou efetivamente à regência da escrivania de Perpignan no mês de janeiro de $1258^{110}$.

O segundo estabelecimento é um pouco diferente, pois não concerne ao regente do estudo perpignanais, mas a seu substituto. No dia 19 de março de 1269, de passagem na capital do Roussillon, o rei de Aragão confirmou a Arnaldo Miró, escrevente público de Perpignan, a escrivania desta vila, com tudo isso que relevava deste ofício. Uma cláusula precisava que esta concessão valia por todo o tempo que Raimundo Eimeric, regente deste estudo, o tivesse instituído escrevente público, a saber, do dia 11 de fevereiro até 24 de junho, e para os três anos que se seguiriam a esta data, conforme o que está estipulado no registro de investidura feito e aprovado por Raimundo Eimeric. É assinalado que Arnaldo deveria ter este ofício correta e lealmente; por outro lado, ele deveria pagar ao conde-rei o censo cujo montante era estipulado no registro que trazia a concessão deste estudo a Raimundo Eimeric. Enfim, se Raimundo Eimeric morresse no curso desta concessão, aquilo, não obstante, permaneceria válido até seu término.

Este documento é rico de informações: em primeiro lugar, é interessante constatar que o dia fixado para o término da concessão do ofício notarial era o dia 24 de junho, dia da festa de São João Batista, patrono da paróquia primitiva de Perpignan ${ }^{111}$. O exame dos protocolos ou das notas breves do fim do século XIII e do início do seguinte confirma plenamente esta informação, pois se observa que os primeiros registros datavam geralmente 
$\overline{\text { do dia } 24 \text { de junho ou dos dias que se seguiam. O mesmo calendário estava em vigor em }}$ Puigcerdà, na primeira metade do século $\mathrm{XIV}^{112}$.

Por outro lado, isso mostra como funcionava o sistema dos substitutos no seio do estudo perpignanais. O regente, que tinha, provavelmente, a escrivania em caráter vitalício, podia, na ocasião, conceder o usufruto dela a um suplente, por uma duração determinada, segundo as modalidades acordadas em um contrato, cabendo ao substituto fazer ratificar esta delegação de poder pela autoridade competente, como o fez Arnaldo Miró, na ocasião de uma jornada de seu soberano a Perpignan.

Arnaldo Miró, como a maior parte de seus colegas, iniciou, muito provavelmente, sua carreira por um período de aprendizagem no seio do estudo de Perpignan. Nós o descobrimos escrevendo sob a direção do notário público Guilherme de Freixenet, de fevereiro a dezembro de $1252^{113}$. Em seguida, ele desapareceu da documentação durante mais de dez anos, para somente reaparecer no mês de junho de $1264^{114}$. Ele redigiu registros sob a autoridade do escrevente público Pedro Calvet. Não se pode, infelizmente, conhecer os motivos de uma tão longa ausência, que seria tentado atribuir a uma viagem destinada à aquisição de uma formação complementar. Sempre e após alguns meses passados no serviço do experiente Pedro Calvet, Arnaldo Miró alcançou o seu prestígio, após sua morte, ocorrida, sem dúvida, pouco antes de julho de 1265. Arnaldo sustentava, desde então, o título de escrevente público $^{115}$. Parece, todavia, que ele somente tinha assumido a regência do estudo de Perpignan de maneira transitória até o verão de 1266. As subscrições nos informam, de fato, que a escrivania foi concedida ao escrevente público Raimundo Eimeric, no mais tardar, em setembro de $1266^{116}$. A partir deste momento, é como substituto deste novo regente que Arnaldo Miró subscrevia os registros ${ }^{117}$. A concessão real que lhe fora outorgada em março de 1269 só fez, consequentemente, confirmar a prorrogação por três anos suplementares de seu contrato de substituto. Restaria, todavia, explicar o fato que, desde o mês de setembro de 1268, Arnaldo Miró cessou de exprimir em sua fórmula de corroboração o fato que ele exercia seu ofício em virtude de uma delegação de poder de Raimundo Eimeric ${ }^{118}$. De qualquer modo, o estudo dos registros roussillonnais confirma que Arnaldo exerceu efetivamente a regência do notariado de Perpignan até o mês de julho de 1272, ou seja, um pouco além do limite fixado no contrato ${ }^{119}$. Durante este período, ele foi levado a redigir muitos documentos do ano 1267 a partir das notas de seu predecessor ${ }^{120}$.

Durante os três últimos anos de seu exercício, ao menos doze escreventes diferentes trabalharam sob a direção de Arnaldo Miró. Na segunda metade do século, o número de profissionais do escrito ativos na capital do Roussillon não cessou, de fato, de R. Fac. Dir. UFG, v. 39, n.2, p. 43 - 86, jul. / dez. 2015 


\section{PRELÚDIO A HISTÓRIA DO NOTARIADO PÚBLICO EM PERPIGNAN E NO}

CONDADO DE ROUSSILLON (1184-1340)

crescer, testemunhando a vitalidade demográfica e econômica da vila. Um dos corolários desta expansão, sem dúvida, foi o aumento da qualidade dos registros recebidos cotidianamente junto à escrivania. Concebe-se suficientemente a sobrecarga de trabalho no ofício que devia ocasionar o fato que um único responsável, o regente ou seu substituto, tinha a faculdade de subscrever, logo, de conferir seu valor autêntico aos instrumentos públicos no momento de sua expedição in mundum.

Foi para remediar os problemas induzidos por esta situação que, no dia primeiro de março de 1273, os cônsules de Perpignan obtiveram do rei de Aragão, que o batlle real desta vila pudesse, doravante, instituir, por sua autoridade, um escrevente suplementar na escrivania, quando ele estimasse que o regente não fosse suficiente parar expedir os registros públicos. A tradução diplomática desta decisão relativa à criação de um notário adjunto se verifica nos escatocolos dos documentos instrumentados alguns meses mais tarde. Assim, em sua fórmula de autenticação de um registro datado de 26 de maio de 1273, Pedro Fabre de Capcir, escrevente público de Perpignan, tomou o cuidado de precisar que ele subscrevia os registros recebidos em poder do regente Bernardo Carles por causa da autoridade que lhe fora conferida pelo juiz ordinário de Perpignan e de Roussillon, Pedro Roig, pelo tenente do batlle de Perpignan, Martí del Trilar, e pelo regente da escrivania ${ }^{121}$.

Esta primeira medida não conseguiu conter, por muito tempo, o fluxo incessante das transações concluídas na nova capital continental da Coroa de Mallorca. Também, os cônsules de Perpignan obtiveram, desde o dia 15 de janeiro de 1277, uma ordenação de seu novo soberano, Jaime II, instituindo que, antes da próxima festa de Saint-Jean, em junho, fossem estabelecidos, em dois lugares distintos desta vila, duas escrivarias. O monarca ordenava que um tabelião ou notário público residisse em cada um destes estudos, a fim de exercer seu ofício.

A aplicação desta ordenação é assaz difícil de observar em nossa documentação, onde os anos 1276 e 1277 são pouco representados. Constata-se, entretanto, que dois escreventes púbicos coexistiram efetivamente a partir de julho de 1277: Arnaldo Miró, que estava no posto desde o mês de agosto de 1275, e Pedro Fabre de Capcir, que, como temos visto, tinha sido feito notário adjunto após a reforma de 1273. Sua subscrição, que não fazia mais referência a qualquer delegação de poder, pode levar a presumir, razoavelmente, que ele tomara a cabeça do segundo estudo instituído pelo rei de Mallorca. Esta presunção parece ser corroborada pelo fato de que não são os mesmos escreventes que instrumentavam sob a autoridade respectiva destes dois regentes do notariado perpignanais ao curso dos anos 1277 - 
1278. Esta conjunção de indícios é suficiente, em minha opinião, para atestar a existência de dois ofícios distintos e, por consequência, a execução efetiva da decisão real.

Constata-se que, no século XIII, os profissionais que tinham o ofício junto do(s) estudo(s) de Perpignan traziam majoritariamente o título de scriptor publicus. A locução notarius publicus, de um uso menos frequente, apareceu pela primeira vez trazida por Raimundo Carles (janeiro de 1242 - novembro de 1244) e, depois, por três de seus sucessores, regentes da escrivania de Perpignan em meados do século: Raimundo de Vilallonga (janeiro de 1248 - maio de 1249), Guilherme de Freixenet (agosto de 1251 janeiro de 1253) e Guilherme de Sala (novembro de 1258 - julho de 1261). Os documentos roussillonnais da época não permitem operar uma verdadeira distinção semântica entre as duas designações. A natureza da dicotomia sugerida pelo emprego destes dois vocábulos é, de fato, particularmente difícil de discernir. Estar-se-ia tentado a ver aí a expressão de uma hierarquia no seio dos detentores da fides publica. Observam-se, de fato, no fim do século, casos de profissionais que, no curso da carreira, abandonavam o título de escrevente público para se revestir daquele de notário público. Assim, o mallorquino Miguel Rotlan subscreveu na qualidade de escrevente público de Perpignan de outubro de 1287 a outubro de 1296 e como notário público de Perpignan de março de 1295 a junho de 1298, com um período de transição de mais de um ano, durante o qual ele adotou indiferentemente as duas titulações. Assim, o notário se distinguia por um nível de qualificação superior, adquirido seja por força da experiência seja pelo viés de um ensino universitário. Sabe-se que, na pequena cidade catalã de Vic, a formação do scriptor publicus se limitava a um período de aprendizagem de quarto anos junto ao estudo ${ }^{122}$. As fontes não permitem, infelizmente, verificar se era o caso em Roussillon. Porém, uma coisa é certa, a diferença potencial do estatuto que distinguia o escrevente público do notário público não constituía um fator discriminatório para a atribuição da regência da escrivania.

A segunda metade do século XIII foi marcada por uma tomada de controle do notariado público pelas vilas. Nos condados do norte catalão, este fenômeno foi atestado em Villefranche-de-Conflent e em Puigcerdà, cujas comunidades obtiveram de Jaime I a concessão, a título perpétuo, do notariado de sua vila. As duas concessões enfiteuticas foram estabelecidas segundo um mesmo formulário. A mais antiga, datada de 5 de janeiro de 1254 , concerne a Villefranche-de-Conflent. O rei de Aragão concedeu a sua comunidade de habitantes o notariado desta vila e de todo Conflent, com a faculdade de instituir o escrevente ou os escreventes que eles desejassem que exercesse este ofício. Este notário teria autoridade para elaborar todos os tipos de instrumentos públicos, como se eles fossem diretamente R. Fac. Dir. UFG, v. 39, n.2, p. 43 - 86, jul. / dez. 2015 
instituídos pelo rei. A comunidade fixaria as tarifas de seus ofícios. Na eventualidade onde a comunidade se desinteressasse disto, uma clausula previa que a cessão iria para Ferrer de Mallol e Vidal de Matemale, seguindo as mesmas condições (ALART, 1874, p. 208) ${ }^{123}$.

A cessão do notariado de Puigcerdà teve lugar dez anos mais tarde, em 19 de julho de 1264. Neste dia, Jaime I entregou, em enfiteuse, para a comunidade dos habitantes de Puigcerdà a escrivania desta vila e de toda a Cerdagne, que era antão mantida pelos notários Pedro Ripoll e Pedro Gisclavar ${ }^{124}$. Ele lhes concedeu a faculdade de criar e de destituir os escreventes por sua própria autoridade e de receber seus emolumentos conforme a tarifa costumeira. Ele instituiu, por outro lado, que os escreventes fossem designados ou transferidos por um colégio de doze bons homens eleitos pelo conselho da universidade dos habitantes, mas ele lhes interditou de instituir clérigos neste ofício. O Conquistador revogou a concessão que ele havia feito anteriormente a Pedro Ripoll e Pedro Gisclavar, explicando sua decisão pelo fato de que Pedro Ripoll fizera provas de imoralidade ao oferecer assistência ao assassino de um judeu.

Como contrapartida a estas concessões, prodigas de rendimentos para os caixas municipais, as duas comunidades eram obrigadas a verter um censo anual, metade paga no Natal, metade no dia de São João, em junho. O montante disso era fixado em 600 soldos de moeda de Melgueil para a comunidade de Villefranche-de-Conflent e em 800 soldos para aquela de Puigcerdà. Admitindo que o montante do censo fosse indexado sobre uma estimativa da rentabilidade do ofício público, o superávit de 200 soldos, seja 33\%, pago para a universidade de Puigcerdà, pode ser interpretado como o indício de uma maior atividade econômica distinguindo o vicariato de Cerdagne daquele do Conflent. Observa-se, de fato, que nos dois casos, as concessões da prerrogativa notarial recaiam sobre o conjunto do território submetido à jurisdição dos dois lugares chefe do vicariato. É necessário, contudo, relativizar a importância destas concessões, salientando que o controle de uma parte considerável destas jurisdições escapava das vilas em razão da presença de numerosos enclaves territoriais, cuja autoridade relevava de senhores que detinham o controle sobre o notariado. Era o caso, notadamente, dos vilarejos dependentes da jurisdição das abadias de São Miguel de Cuixà, de São Martin de Canigou ou do priorado de Corneilla-de-Conflent ${ }^{125}$.

Escapando ao poder consular, a situação do notariado perpignanais diferiu sensivelmente daquela de Villefranche e de Puigcerdà. Esta diferença de política é, em uma primeira abordagem, difícil de explicar. Pode-se emitir a hipótese de que o rei não desejasse delegar esta prerrogativa à municipalidade, julgando preferível se reservar o controle e, 
sobretudo, os rendimentos, que, se supunha amplamente mais importantes do que aqueles das duas outras vilas pirenaicas. Nós ignoramos o montante anual dos rendimentos que o ofício público rendia a Coroa sob o reinado de Jaime I. As únicas cifras de que dispomos para apreciar a rentabilidade do notariado perpignanais nesta época são, de um lado, os 500 soldos de moeda de Melgueil de censo anual exigidos por Jaime I no registro que ele concedia a regência do estudo a Pedro Calvet em janeiro de 1258, e, de outro, a renda anual de 400 soldos de moeda de Melgueil a receber no dia de Natal sobre os rendimentos do notariado de Perpignan, atribuída ao mosteiro de Santa Maria de Fontfroide pelo mesmo rei alguns dias antes, em 15 de dezembro de 1257, na ocasião de uma importante troca de senhorio contraída com os cistercienses ${ }^{126}$. Nós dispomos, em compensação, de uma cifra particularmente edificante para o reinado de Jaime III de Mallorca, período correspondente ao apogeu medieval da capital do condado de Roussillon. Uma relação dos rendimentos da Coroa, redigida em 1333, nos informa, de fato, que o montante anual ao qual estavam ligadas as duas escrivanias perpignanaises se elevava, então, a soma considerável de 855 Libras, o que perfazia o segundo posto mais lucrativo da vila após os rendimentos da leude maior ${ }^{127}$.

A organização interna da profissão é bem difícil de perceber: são raros os indícios permitindo saber como funcionava a sociedade dos notários antes da criação do colégio dos notários de Perpignan pelo reio de Aragão, Pierre IV, em $1355^{128}$. Parece, todavia, que certa forma de corporativismo já unia os praticantes perpignanais no início do século XIV, como o atesta uma reivindicação formulada pelos delegados dos tabeliões indignados por terem que pagar aos coletores dos rendimentos reais provenientes das escrivanias o preço dos registros que eles faziam por sua própria conta nos estudos da vila.

No dia 22 de outubro de 1309, os dois regentes, Arnaldo Ysern e Nicolau Camot, compareceram ao palácio real a fim de obter de Jaime II a gratuidade dos registros destinados a seu uso pessoal. Aquiescendo favoravelmente a esta demanda, o rei de Mallorca ordenou que todos os escreventes dos estudos e dos outros ofícios reais, tendo o poder de anotar, redigir e escrever registros, fossem, doravante, isentos e livres de prestações sobre o preço de seus próprios docuementos, testamentos e outros instrumentos públicos. Este privilégio, que concernia igualmente aos notários e aos oficiais de registros das cortes soberanas, foi confirmado pelo rei Sancho no dia primeiro de fevereiro de 1324. Ele rejeitava, assim, uma reivindicação dos cobradores de impostos que desejavam limitar o alcance da ordem real somente aos depositários da fides publica, excluindo os aprendizes e os escreventes que exerciam o ofício sob sua autoridade. 
Sob o reinado dos reis de Mallorca, o ofício público foi tema de uma legislação cada vez mais estrita, visando melhorar seu funcionamento e remediar os diferentes inconvenientes e abusos resultantes da falta de enquadramento das práticas da escritura junto das escrivanias. Negligentes, às vezes francamente corruptos, descuidando frequentemente de seu trabalho a fim de aumentar seus proveitos, os tabeliães perpignanais não tinham uma boa reputação. Ao fim do primeiro decênio do século XIV, os procuradores do rei de Mallorca, Pedro de Bardoyl e Pedro Matfré, responsáveis pela administração dos diferentes ofícios públicos nos condados de Roussillon e de Cerdagne, constataram que as práticas fraudulentas de alguns escreventes afetavam os rendimentos dos dois estudos perpignanaises: alguns dissimulavam uma parte dos emolumentos recolhidos pela recepção dos registros, enquanto outros, para ganhar tempo e aumentar seus benefícios, se dispensavam de registrar suas notas nos protocolos.

Para remediar esta má administração, os procuradores reais editaram, em 26 de novembro de 1310, um conjunto de medidas visando melhorar o controle da atividade dos escreventes e, assim, aumentar a rentabilidade deste ofício, cuja parte dos rendimentos era vertida à Coroa. Pedro de Bardoyl e Pedro Matfré, procuradores do rei da Mallorca, proibiaram aos escreventes Arnaldo Ysern e Nicolau Camot, mestres e regentes das duas escrivanias de Perpignan, e aos escreventes que tomavam notas sob sua chancela, de inscrever os nomes das testemunhas das cartas e dos contratos que eles recebiam, se o preço do registro não lhes fosse pago. Eles lhes ordenavam indicar sistematicamente a soma que recebessem pelo preço de cada registro anotado, sob pena de incorrer na justiça do rei e de ter de pagar, eles mesmos, o preço devido pelos registros que eles tivessem anotado.

Em complemento deste dispositivo, os procuradores reais instituíram um controlador em cada estudo. Escreventes de formação, Pedro Berengário e Bernardo de Maureillas foram encarregados de procurar nos arquivos todas as notas ou cartas recebidas nestas escrivanias, a fim de fazê-las registrar imediatamente e sem qualquer salário para aqueles que tivessem tomado em nota todos os registros "esquecidos". Na eventualidade em que uma pessoa requeresse que lhe fosse entregue um registro, de acordo uma nota tomada outrora em um destes estudos, os controladores deveriam procurar esta nota a fim de registrála; por outro lado, se a nota não mencionasse o pagamento do preço, eles receberiam o preço disso sob o conhecimento dos regentes. O salário de cada controlador era fixado então em 5 libras. 
Além disso, "para a utilidade e o bem comum da vila de Perpignan e do Roussillon" e para motivar os escreventes a registrar os documentos sobre pergaminho, os procuradores reais ordenavam que aqueles recebessem, doravante, o quarto do preço dos registros pelos quais o rei recebia menos de 12 denários; 4 denários para os registros cujo valor era compreendido entre 12 denários e 2 soldos e, para os registros de um montante superior a 2 soldos; 2 denários para cada soldo suplementar. Todo instrumento deveria ser redigido em forma pública, nos protocolos, oito dias seguintes à anotação. No mais, cada registro deveria ser assentado sobre pergaminho nos dois meses seguintes a sua anotação na escrivania, de sorte que ele estivesse pronto a receber a subscrição do regente. Quanto aos instrumentos recebidos fora da escrivania, eles deveriam ser entregues em oito dias se o cliente o requeresse, senão, eles deveriam estar prontos a serem validados em um mês. A pena fixada para aqueles que não registrassem no tempo previsto era fixada pela metade do preço recebido pelo escrevente para a expedição e na totalidade do preço para aqueles que não entregassem a tempo os registros recebidos fora do estudo. Cada pena deveria ser consignada pelo regente nas memórias dos escreventes incriminados. Nenhum regente poderia receber registros fora de seu escritório, postos à parte os testamentos e os codicilos. Nenhum aprendiz formado nas escrivanias de Perpignan poderia começar a tomar notas públicas até que ele tivesse sido reconhecido competente por um júri composto do regente e de três ou quatro escreventes. O escrevente que fosse recolher os registros fora da vila de Perpignan receberia 2 soldos por cada deslocamento e mais em função da distância percorrida. O conjunto destas prescrições deveria entrar em vigor em primeiro de dezembro de $1310^{129}$.

A legislação do ofício público se estendeu por oito anos com uma importante ordenação do chanceler real Arnaldo Traver, que fixava a tarifa dos registros notariados recebidos nos territórios sujeitos a Coroa de Mallorca. Redigido em catalão, este regulamento detalhava, por uma lista, o montante dos emolumentos que os praticantes estavam no direito de receber por seu trabalho. Compreendido entre quatro denários e dez soldos, o montante dos registros privados variava em função de seu tipo diplomático, das obrigações que eram estipuladas aí, assim como do valor numerário das transações que eram consignadas ${ }^{130}$.

Para ganhar tempo, os escreventes tinham tomado o hábito de registrar suas nótulas (minutas) sob forma de breves, utilizando numerosas abreviações e se limitando a indicar nas cláusulas dispositivas todas a primeiras palavras das fórmulas jurídicas abreviadas no meio da locução et Cetera. Esta prática somente podia suscitar confusões quando da ocorrência de registros extensos e de sua formalização pública, sobretudo se isso ocorresse 


\section{PRELÚDIO A HISTÓRIA DO NOTARIADO PÚBLICO EM PERPIGNAN E NO CONDADO DE ROUSSILLON (1184-1340)}

muitos meses ou muitos anos após a anotação, no momento em que a memória dos fatos já tinham deixado o espírito do escrevente que o tivesse recebido.

Em um mandado endereçado, no dia 5 de setembro de 1334, a todos seus oficiais do reino de Mallorca e dos condados de Roussillon e de Cerdagne, Jaime III lhes emitia a ordem de executar um conjunto de decisões concernentes, de uma parte, aos escreventes e notários curiais e, de outra, aos escreventes e notários públicos. Ele instituiu que, doravante, todos os notários e os escreventes deveriam redigir em suas notas e protocolos a integralidade dos contratos, testamentos, codicilos e outros registros, quaisquer que fossem, sem recorrer a locução et cetera ou a abreviações, nem usar subentendidos, de maneira que estes documentos tivessem exatamente o teor dos instrumentos redigidos in mundum ${ }^{131}$. A fim de evitar os erros, intencionais ou não, que se produziam quando da expedição dos breves, o rei impôs a todos os tabeliões que exerciam o ofício nas ilhas Baleares e nos condados de Roussillon e de Cerdagne a manutenção de um extensório. Segundo o mesmo princípio, para reduzir os erros imputados às inevitáveis limitações da memória, Jaime II ordenou, em seguida, que todo notário ou escrevente que recebesse o registro de um contrato ou de um assunto qualquer sobre cédula ou sobre outro suporte diferente de seu livro ou protocolo era, doravante, obrigado a redigir, por extenso, em seu protocolo, nos oito dias seguintes. Todo contraventor incorreria em uma pena de 10 libras por cada infração cometida.

A consequência direta desta nova regulamentação foi um considerável aumento da carga de trabalho dos escreventes. Eles não tardaram a demonstrar ao rei que a redação dos documentos, por extenso, em seus registros, constituía um acréscimo de labor e que convinha, em consequência, uma remuneração por seus registros. No início do mês de dezembro de 1334, a fim de não trazer prejuízo aos interesses dos profissionais, Jaime III promulgou uma nova tarifação dos emolumentos que eles deveriam receber em função das diferentes categorias dos registros.

A questão dos honorários estava novamente na ordem do dia em 24 de março de 1339, em uma ordenação de Miguel Amarell, procurador do rei de Mallorca, que regulamentava o notariado de Perpignan. Foi estipulado que, doravante, cada notário pagaria ao rei a metade do preço dos instrumentos de todos os contratos que fossem recebidos e anotados, conservando a outra metade. Em caso de deslocamento fora da vila para receber documentos, os notários deveriam dar ao rei doze denários por légua percorrida. Foi estabelecido que os profissionais deviam comprar o papel, o pergaminho e a tinta que eles tivessem necessidade com sua metade dos rendimentos. Eles foram, igualmente, obrigados a 
expedir os instrumentos em forma pública, arcando com seus custos. O prazo da inserção no protocolo ou no extensório do instrumento de um contrato recebido verbalmente ou tomado sobre uma cédula era prologando para dez dias, no lugar dos oito prescritos na ordenação de 1334. Cada notário, quando fosse requisitado, devia fazer as contas com os procuradores do rei ou com sua delegação e pagaria, em numerário, a parte devida ao rei, imediatamente após as contas serem feitas; ninguém podia exercer o ofício até que fosse paga esta contribuição. Foi formalmente interditado aos escreventes de serem enviados para redigir os instrumentos in mundum sem terem recebido previamente a autorização dos procuradores reais ou de um de seus representantes. Do mesmo modo, ninguém podia exercer o ofício público até que passasse por um exame, conforme uma antiga ordenação real.

Em seguida, a ordenação fixava, pela metade do preço do contrato, os estipêndios que os notários podiam exigir além da tarifa normal para os registros recebidos fora da escrivania; e se eles se deslocassem muitas vezes para o mesmo contrato, eles estariam no direito de reclamar mais seis denários por cada deslocamento. Para os registros recebidos no estudo, os notários deviam receber a tarifa habitual e as cartas fragmentadas deveriam ser tarifadas como se fosse um único instrumento. Todo contraventor incorreria em uma multa de dez soldos de Barcelona por cada infração, cuja metade devia ser paga ao rei e a outra metade ao caixa comum das escrivanias. O procurador lembrava, enfim, o costume que estipulava aos notários de receberem, redigirem e fazerem expedir gratuitamente os documentos concernentes ao rei.

Três dias mais trade, em 27 de março de 1339, vinte e dois notários mandatários da autoridade pública fizeram o juramento de observar o teor destas ordenações. Em primeiro de abril, oito escreventes e dez aprendizes do novo estudo dito da Buada, cujos contratos deviam ser subscritos por Pedro Montagut, Bernardo Jaubert, Pedro Raül e Guilherme de Bosqueros, sob a direção dos quais estes escreventes e aprendizes eram formados, de uma parte, e sete escreventes e doze aprendizes do antigo estudo, cujos contatos deviam ser subscritos por Guilherme Agut e Guilherme Miaffré, de outra parte, obtiveram o poder de anotar, receber e expedir os registros. Constata-se que, sob o reinado da dinastia de Mallorca, o notariado perpignanais tomou uma amplitude considerável, pois, ao curso destes sessenta anos, o número de depositários da fides publica que operavam nos dois estudos da vila, passou de dois para vinte e dois; já o número de praticantes, escreventes e aprendizes, de uma pequena dezena passou a quarenta e sete!

Por fim, convém evocar esta carta de 27 de abril de 1340, pela qual Jaime III concedera a cada um de seus notários, Lorenço Huguet, Guilherme Moner, Antônio Cotlliure, R. Fac. Dir. UFG, v. 39, n.2, p. 43 - 86, jul. / dez. 2015 
Francisco Ferrer, Francisco Banyuls, Guilherme Beló e Pedro Raül, o direito de redigir e fazer redigir, a partir de seus próprios protocolos e por substitutos idôneos, os registros recebidos por notários mortos ou ausentes, criados por sua autoridade, com a condição de que estes documentos não fossem corrompidos ou cancelados e nada fosse acrescentado, mudado ou retirado.

O estudo da aparição e do desenvolvimento do notariado em Perpignan e no condado de Roussillon testemunha, deste modo, a importância da renovação jurídica que afetou as sociedades do Ocidente cristão nos séculos XII e XIII. Parte de suas inumeráveis implicações, a ascensão da instituição notarial constituiu um evento de primeira importância que participava, em grande medida, do advento da modernidade. Sobre este ponto, o campo de investigação permanece amplamente aberto e somente nos resta esperar que outros estudos venham corrigir ou enriquecer com novas abordagens temáticas a presente contribuição, pois, neste assunto, questões ainda permanecem em suspenso...

\section{REFERÊNCIAS}

ALART, B. Privilèges et titres relatifs aux franchises, institutions et propriétés communales de Roussillon et de Cerdagne depuis le $\mathrm{XI}^{\mathrm{e}}$ siècle jusqu'à l'an 1660 ... Première partie, 1000-1276, Perpignan: Latrobe, 1874.

ALEJANDRE GARCÍA, J.A. El arte de notaría y los formulários. In: Revista de Historia del Derecho, vol. II, 1977-1978, p. 189-220.

ALTURO, Jesús. Le statut du scripteur en Catalogne (XII - XIII ${ }^{\mathrm{e}}$ siècle). In: HUBERT, MarieClotilde (dir.); POULLE, Emmanuel (dir.)\& SMITH, Marc. H (dir.). Le statut du scripteur au Moyen Age. Paris: École des Chartes, 2000, p. 41-50.

BAIGES i JARDÍ, Ignasi J. El notariat català: origen i evolució. In: SANS i TRAVÉ, Josep Maria (coord.) Actes del I Congrés d'història del notariat català (Barcelona, 11,12 i 13 de novembre de 1993), Barcelona: Fundació Noguera, 1994, p. 131-166.

BARTOLI LANGELI, A. "Il notariato", Genova, Venezia, il Levante nei secoli XII-XIV. In: ORTALLI, Gherado (org.) \& PUNCHUH, Dino (org.). Atti del convegno (Genova, 10-14 marzo 2000). Atti dela Società ligure di storia patria, XLI/1, 2001, p. 73-102.

BERTRAN ROIGÉ, Prim. Estudiants catalans a la Universitat de Bolonya (segle XIII). In: Acta historica et archaelogica mediaevalia, $\mathrm{n}^{\text {os }}$. 23-24, 2002-2003 (Home-natge al prof. J. R. JULIA VIÑAMATA), 2003, p.123-143. 
BISSON, Thomas N. Ramon de Caldes (c. 1135-c. 1200): Dean of Barcelona and King's Minister. In: Medieval France and her Pyrenean neighbours. Studies in early institutional history. London-Ronceverte: Hambledon Press, 1989, p. 187-198.

BONO-HUERTA, José. Historia del Derecho Notarial Español, t. I et II. Madrid: Junta de Decanos de los Colegios Notariales de España, 1979 et 1982.

BOSOM i ISERN, Sebastià, GALCERAN i VIGUÉ, Salvador. Catalèg de protocols de Puigcerdà. Barcelona: Fundació Noguera, Barcelona, 1983.

BRÉCHON, Franck. Autour du notariat et des nouvelles pratiques de l'écrit dans les régions méridionales aux XII ${ }^{\mathrm{e}}$ et XIII ${ }^{\mathrm{e}}$ siècles: ALEXANDRE-BIDON, D (dir.). \& P. GUICHARD (dir.). Comprendre le XIII ${ }^{\mathbf{e}}$ siècle. Mélanges offerts à Marie-Thérèse Lorcin. Lyon: Presses Universitaires de Lyon, 1995, p. 161-172.

BRUTAILS, Jean-Auguste. Étude sur la condition des populations rurales du Roussillon au Moyen Age. Paris: Imprimerie Nationale, 1891.

CARRERAS y CANDI, Francesch. Desenrotllament de la institució notarial a Catalunya en el segle XIII. In: Ier Congrés d'Historia de la Corona de Aragó dedicat al rey en Jaume I y a la seva época, vol. II. Barcelona, 1913, p. 751-789.

CHASTANG, Pierre. Lire, écrire, transcrire. Le travail des rédacteurs de cartulaires en Bas-Languedoc (XI ${ }^{\mathrm{e}}-\mathrm{XIII}{ }^{\mathrm{e}}$ siècles). Paris: CTHS, 2002.

CONDE y DELGADO DE MOLINA, Rafael. El pas de l'escrivà al notari. In: SANS i TRAVÉ, Josep Maria (coord.) Actes del I Congrés d'història del notariat català (Barcelona, 11,12 i 13 de novembre de 1993), Barcelona: Fundació Noguera, 1994, p. 439462.

COSTAMAGNA, Giorgio. Il notariato nell'Italia settentrionale durante i secoli XII e XIII. In: Notariado públíco y documento privado: de los orígenes al siglo XIV. Actas del VII Congreso Internacionál de Diplomática (Valencia, 6-12 ottobre 1986), II. Valencia: Conselleria de Cultura Educació i Ciència, 1989, p. 991-1008.

COTS GORCHS, Jaume. Textos de dret rossellonès. L'antic llibre dels privilegis de Colliure. In: Estudis Universitaris Catalans, XVI i XVII. Barcelona, 1931, p. 340-357, et 1932, p. $65-85$.

DAILEADER, Philip. True Citizens: Violence, Memory and Identity in the Medieval Community of Perpignan 1162-1397. Leiden, Boston, Köln: Brill, 2000.

DE BOÜARD, A. Manuel de diplomatique française et pontificale. T. II. L'acte privé. Paris: Auguste Picard, 1948.

DENJEAN, Claude. Crédit et notariat en Cerdagne et Roussillon du XIII ${ }^{\mathrm{e}}$ au XV $\mathrm{XV}^{\mathrm{e}}$ siècle. In: MENANT, François (dir.) et REDON, Odile (dir.). Notaires et crédit dans l'Occident méditerranéen médiéval. Collection de l'École Française de Rome-343. Rome: Ecole Française de Rome, 2004, p. 185-206. 
DOSSAT, Yves. Unité ou diversité de la pratique notariale dans les pays de droit écrit. In: Annales du Midi, t. 68, 1956, p. 175-184.

DURAN y CAÑAMERAS, F. Nota para la historia del notariado catalán. In: Estudios y documentos de los Archivos de Protocolos, III. Barcelona, 1955, p. 71-207.

EXTREMERA, Miguel Ángel. El notariado en la España medieval (siglos XIII-XV). Balance historiográfico y líneas de investigación. In: Actas II simposio de Jóvenes Medievalistas. Lorca (2004). Múrcia, 2006, p. 37-49.

FERRER i MALLOL, Maria Teresa. La redacció de l'instrument notarial a Catalunya: cèdules, manuals, llibres i cartes. In: Estudios Históricos y Documentos de los Archivos de Protocolos, IV. Barcelona, 1974, p 29-211.

L’instrument notarial: concepte i evolució (s. XI-XV).

In: Actes del II Congrès d'Història del Notariat Català. Barcelona, 2000, p.29-88.

FONTAINE, Denis et LANGÉ, Christine. Présentation des fonds de notaires conservés aux Archives départementales des Pyrénées-Orientales. In: Documentació notarial i arxius. Els fons notarials com a eina per a la recerca histórica. Girona, 5 et 6 octobre 2006, p. 102-109.

GAULIN, Jean-Louis. Affaires privées et certification publique. La documentation notariale relative au crédit à Bologne au XIII ${ }^{\mathrm{e}}$ siècle. In: MENANT, François (dir.) \& REDON, Odile (dir.). Notaires et crédit dans l'Occident méditerranéen médiéval. Collection de l'École Française de Rome-343. Roma: École française de Rome, 2004, p. 55-95.

GINEBRA i MOLINS, Rafel. El manual primer de l'Arxiù de la Curia Fumada de Vic, 1230-1233. 2 vols. Barcelona: Fundació Noguera, 1998.

. Un fragment de llibre notarial de 1221 a l'Arxiu de la Cúria Fumada de Vic. In: Estudis històrics i documents dels arxius de protocols, $n^{\circ} .19$ (2001), p. $7-22$.

GOURON, André. Diffusion des consulats méridionaux et expansion du droit romain aux $\underline{\text { XII }^{\mathrm{e}} \text { et XIII }} \mathrm{e}^{\mathrm{e}}$ siècles. In: Bibliothèque de l'École des Chartes. Tome CXXI. 1963, p. 55-76.

du Midi, t. 69, 1957, p. 103-120.

Les étapes de la pénétration du droit romain en Septimanie. In: Annales

GUILLERÉ, Christian et PINTO, Anthony. Bilan des recherches sur le notariat géronais (XIII $-\mathrm{XV}^{\mathrm{e}}$ siècles). In: Documentació notarial i arxius, Els fons notarials com a eina per la recerca històrica, 5-6 d'octubre 2006. Girona, 2007, p. 35-69.

HUICI MIRANDA, Alberto (éd.) \& CABANES PECOURT, Maria Desamparados (éd.). Documentos de Jaime I de Aragón (1216-1268). 5 vols. Valencia-Zaragoza: Anubal, 19761988.

KOSTO, Adam J. Making agreements in medieval Catalonia: power, order, and the written world, 1000-1200. Cambridge: Cambridge university press, 2001. 
LARGUIER, Gilbert. Fiscalité et institutions à Perpignan (XII ${ }^{\mathrm{e}}-\mathrm{XVIII}^{\mathrm{e}}$ siècles). In: ASSIER ANDRIEU, Louis (dir.) et SALA, Raymond (dir.). La ville et les pouvoirs. Actes du Colloque du Huitième Centenaire de la Charte de Perpignan, 23/25 octobre 1997. Perpignan : Presses universitaires de Perpignan, 2000, p. 435-448.

LARGUIER, Gilbert. Les paysans et leur notaire dans la province du Roussillon. In: LAFFONT, Jean-Luc (éd.). Le notaire, le paysan et la terre. Toulouse: PUM, 1999, p. 185215.

LÉONARD, Émile-G. Catalogue des actes des comtes de Toulouse, Raymond V (11491194). Paris: Picard, 1932.

MASSOT-REYNIER, Joseph (org.). Les coutumes de Perpignan. Montpellier: Société Archéologique de Montpellier, 1848 (Réimpr. Marseille, 1976).

MENANT, François (dir.) \& REDON, Odile (dir.). Notaires et crédit dans l'Occident méditerranéen médiéval. Collection de l'École Française de Rome-343. Roma: École française de Rome, 2004.

MONTSALVATJE Y FOSSAS, Francisco. Noticias Historicas. 26 vols. Olot, 1889-1910.

MIQUEL ROSSELL, Francisco. Liber Feudorum Maior, Cartulario real que se conserva en el Archivo de la Corona de Aragón. Barcelona: Consejo Superior de Investigaciones Científicas, Sección de Estudios Medievales de Barcelona, 1945 et 1947.

MIRET I SANS, Joaquim. Escolars catalans al Estudi de Bolonia en la XIII ${ }^{\mathrm{a}}$ centúria. In: Boletín de la Real Academia de Buenas Letras de Barcelona. Vol. XV, 1915, p. 137-155.

NOGUERA GUZMÁN, Ramon (dir.) y Josep Maria MADURELL MARIMON (dir.). Privilegios y ordenanzas históricos de los notarios de Barcelona. Centenario de la Ley del Notariado, Sección cuarta. Fuentes y Bibliografia. vol. II, t. I, Barcelona, 1965.

PAGAROLAS i SABATÉ, Laureà. Notaris i auxiliars de la funció notarial a les escrivanies de la Barcelona medieval. In: Lligall. Revista Catalana d'Arxivistica, n ${ }^{\circ}$ 8, 1994, p. 53-72.

Gènesi i evolució dels registres notarials (segles XIII-XIX).

In: Actes del II Congrés d'Història del Notariat Català. Barcelona, 2000, p. 161-184. (coord.), Els fons de protocols de Catalunya. Estat actual i proposta de sistematització. Barcelona: Associació d'Arxiver de Catalunya, 2005.

PÉREZ MARTINEZ, Lorenzo (éd.). Corpus documental balear. Reinado de Jaime I (1228-1235). Fontes rerum Balearium. Vol. I. Palma de Mallorca, 1977.

PEYTAVÍ DEIXONA, Joan. El manual de 1700 de Jaume Esteve, notari de Perpinyà. Barcelone: Fundació Noguera, 2004.

PONS i GURI, Josep Maria. Característiques paleogràfiques dels llibres notarials catalans, fins al 1351. In: Recull d'estudis d'història jurídica catalana. Barcelona, 1989, p. 191-218; 
De l'escrivent al notari i de la "charta" a l'instrument. Recepció dels usos notarials itàlics a Catalunya. In: Lligall. Revista catalana d'Arxivistica, $\mathrm{n}^{\circ} .7$, 1993, p. 29-42.

PONS I GURI, Josep Maria (éd.) et alii (éd.). Manual d'Alcover (anys 1228-1229). In: De scriptis notariorum (s. XI-XV), (Rubrica 3). Barcelona: Universitat de Barcelona, 1989, p. 161-294.

PUIG I USTRELL, Pere (éd.). Capbreu primer de Bertran acòlit, notari de Terrassa, 1237-1242. 2 vols. Barcelona: Fundació Noguera, coll. Acta notariorum Cataloniae, 1992.

RACINE, Pierre. Le notaire au service de l'Etat communal italien (XII ${ }^{\mathrm{e}}-\mathrm{XIII}{ }^{\mathrm{e}}$ siècles). In: Les serviteurs de l'État au Moyen Âge. Actes du XXIX ${ }^{\mathrm{e}}$ Congrès de la SHMESP, Pau, 1998, Paris : Publications de la Sorbonne, 1999, p. 63-74.

RAMON i VINYES, Salvador et FUENTES i GASÓ, Manuel M. Inventari dels protocols notarials de l'Arxiu Històric Arxidiocesà de Tarragona. Barcelona: Departament de Cultura de la Generalitat de Catalunya, 1987.

SAÏDI, Karim. Seings manuels des scribes et notaires du XI $\mathrm{XI}^{\mathrm{e}}$ au XIII ${ }^{\mathrm{e}}$ siècle dans le Roussillon et l'Hérault. In: Les cahiers de Saint-Michel de Cuxa. Tome: XXXVIII, 2007, p. 207-213.

Seing manuel et notariat en pays de droit écrit du $\mathrm{XI}^{\mathrm{e}}$ au $X V^{\mathrm{e}}$ siècle. Diplôme de Master, $2^{\mathrm{e}}$ année d'Histoire, Université de Perpignan, 2005-2006.

Persona et fides publica : pratique et praticiens du notariat au Moyen Âge (XIe-XIVe siècles). Diplôme de Master, $2^{\mathrm{e}}$ année de droit comparé, Université de Perpignan, 2006-2007.

SCHMIER, Benedict (org.) \& PISTORIUS, Marcus Antonius Benedictus (org.). Decretalium Gregorii papae IX, Compilationis, lib. III, tit. L, cap. VIII. Salisburg: Mayr, 1719.

STIENNON, Jacques. Paléographie du Moyen Âge. $2^{\text {ème }}$ édition. Paris: Armand Colin 1991, p. 181.

TORRAS i SERRA, Marc; MASATS i SURIÑACH, Bartomeu; VALDENEBRO i MANRIQUE, Raquel \& VIRÓS i PUJOLÀ, Lluís. Catàleg dels protocols notarials de Manresa, 2 vols. Barcelona: Fundació Noguera, 1993.

TRÉTON, Rodrigue. Un prototype ? Remarques à propos d'un capbreu des revenus et usages du comte d'Empúries dans le castrum de Laroque-des-Albères fait en 1264. In: CAMIADE, Martine (dir.). L'Albera, Terre de passage, de mémoires et d'identités. Actes du colloque de Banyuls-sur-Mer (3-4 mai 2005). Saint-Esteve: Presses Universitaires de Perpignan, 2006, p.49-76.

TRÉTON, Rodrigue \& VINAS, Robert. Le testament de Nuno Sanç. In: Études Roussillonnaises, t. XXVII, (no prelo). 
VALLS I SUBIRA, Oriol. La historia del papel en España, siglos X-XVI. t. I, Madrid, 1978-1980.

\author{
W. EMERY, Richard. The Jews of Perpignan in the thirteenth century an economic \\ study based on notarial records. New York: Columbia University Press, 1959. \\ ZIMMERMAN, Michel. Écrire et lire en Catalogne du $\mathbf{I X}^{\mathbf{e}}$ au XII ${ }^{\mathbf{e}}$ siècle. 2 vols. Madrid : \\ Casa Velázquez, 2003.
} ${ }^{1}$ Esta definição precisa e eficiente, empregada para definir o paradigma bolonhês, foi tomada de Jean-Louis
Gaulin (2004, p. 56).
${ }^{2}$ O valor da prova jurídica do instrumento público era claramente expresso no artigo número 11 dos Costumes
de Perpignan, confirmados pelo rei de Aragão, Jaime I, em 1243 : Item, contra instrumenta scribanie Perpiniani
non admittitur probatio, nisi per testes eorum instrumentorum vel nisi per tabellionem et testes (In: MASSOT-
REYNIER, 1848). Para uma análise do processo histórico que conduziu ao estabelecimento do notário público,
ver A. de Boüard (1948), notadamente, as páginas 163 a 204 .

${ }^{3}$ B. Alart (1874); Jean-Auguste Brutails (1891); Jaume Cots Gorchs (1931, p. 340-357 e 1932, p. 65-85); Gilbert Larguier (2000, p. 435-448); Philip Daileader (2000).

${ }^{4}$ Circunscrições administrativas comparáveis aos nossos departamentos.

${ }^{5}$ Eu somente assinalo algumas obras ou artigos fundamentais para o assunto que nos preocupa aqui. Eu remeto os leitores interessados à numerosa bibliografia especializada disponível na internet: J. A. Alexandre García (1977, p. 189-220); Ignasi J. Baiges i Jardí (1994, p. 131-166); José Bono-Huerta (1979 e 1982); Francesch Carreras y Candi (1913, p. 751-789); Rafael Conde y Delgado de Molina (1994, p. 439-462); F. Duran y Cañameras (1955, p. 71-207); Miguel Ángel Extremera (2006, p. 37-49); Maria Teresa Ferrer i Mallol (1974, p 29-211; 2000, p.29-88); Christian Guilleré e Anthony Pinto (2007, p. 35-69); Ramon Noguera Guzmán \& Josep Maria Madurell Marimon (1965); Laureà Pagarolas i Sabaté (1994, p. 53-72; 2000, p. 161-184; 2005); Josep Maria Pons i Guri (1989, p. 191-218; 1993, p. 29-42).

${ }^{6}$ Richard W. Emery (1959); Sebastià Bosom i Isern \& Salvador Galceran i Vigué (1983); Claude Denjean (2004, p. 185-206); Karim Saïdi, (2007, p. 207-213; 2005-2006; 2006-2007); Denis Fontaine \& Christine Langé (2006, p. 102-109); Gilbert Larguier (1999, p. 185-215); Joan Peytaví Deixona (2004).

${ }^{7}$ Nós, evidentemente, consideramos os registros das chancelarias condais e episcopais.

${ }^{8} \mathrm{O}$ essencial dos materiais utilizados por este artigo provém dos fundos conservados nos Archives départementales des Pyrénées-Orientales em Perpignan (doravante indicados como ADPO) e dos Archives de la Couronne d'Aragon à Barcelone (ACA).

${ }^{9}$ A estreita relação existente entre a emancipação dos governos urbanos e a eclosão do notariado se observa, em primeiro lugar, nas cidades do norte da Península italiana, berço destas instituições, ver, por exemplo, Giorgio Costamagna (1989, p. 991-1008), A. Bartoli Lageli (2001, p. 73-102), Pierre Racine (1999, p. 63-74). Para o Languedoc, reportar-se-á aos trabalhos de André Gouron (1963, p. 55-76) e de Pierre Chastang (2002, p. 272306).

10 No Languedoc, "les premiers spécialistes du droit apparaissent dès 1120 dans la documentation et rapidement la pratique de l'écrit documentaire se modifie", ver Pierre Chastang (2002, p. 272-273). Na Catalunha, o declínio das convenentiae, contratos privados destinados a resolver os conflitos feudais, sobreveio por volta de 1170. Este desaparecimento traduziu, inegavelmente, uma modificação dos hábitos escriturários dos escreventes catalães imputável ao renascimento do direito romano, ver Adam J. Kosto (2001, p. 285 e seguintes).

${ }^{11}$ ADPO, $1 \mathrm{~B} 46$.

${ }^{12}$ Nós ignoramos quase tudo das origens e dos primeiros séculos de existência desta colegial possivelmente fundada na segunda metade do século XI.

${ }^{13}$ Jesús Alturo (2000, p. 42, nota 05) observa que os cônegos barceloneses do século XII quase nunca assinalavam sua dignidade eclesiástica.

${ }^{14}$ Sig+num Petrus scriba, qui hoc per jura scripsit sub die et anno quo supra (SM), ADPO, 1B65. Nota-se igualmente o emprego excepcional nesta subscrição da formula "per jura" que foi encontrada em outros registros consultados.

${ }^{15}$ ADPO, Fonds de l'Hôpital d'Ille, 3B327bis.

${ }^{16}$ Arnaldus levita et monachus Sancti Andree scripsit hanc cartam jussus die et anno (SSS) quo supra: Bibliothèque Nationale de France, Fonds Doat, vol. 59, fol.63.

${ }^{17}$ Importante comendadoria da ordem do Templo implantada a uma quinzena de quilometros ao sul de Perpignan, próxima da principal rota terrestre ligando o continente europeu a Península Ibérica. 


\section{PRELÚDIO A HISTÓRIA DO NOTARIADO PÚBLICO EM PERPIGNAN E NO CONDADO DE ROUSSILLON (1184-1340)}

${ }^{18} \mathrm{Na}$ parte inferior de um registro datado de 23 de outubro de 1181: Arnaldus, Mansi Dei diachonus, scripsit, jussus atque rogatus, (SM) die et anno quo supra, ADPO, Hp191, fol. 161v.

${ }^{19}$ Raimundus, sacerdos et canonicus Sancte Marie de Campo, qui hoc scripsit, cum literis rasis in secunda linea, die et anno quo $S U$-(SM)-PRA, ADPO, 1J193/1.

${ }^{20} \mathrm{Na}$ diocese de Agda, eram os clérigos do capítulo que forneciam o maior contingente dos escreventes de registros privados, consultar Chastang (2001, p. 273).

${ }^{21}$ Sobre a gênese e a evolução da chancela em Roussillon e na região de Montpellier, ver Karim Saïdi (2007, p. 207-213).

${ }^{22}$ No que concerne ao termo notarius, convém de sublinhar que aquele foi empregado muito cedo por certos escreventes da Chancelaria dos condes de Barcelona, como testemunha esta subscrição oposta na parte de baixo de um registro de 1134: Sig+num Poncii, notarii comitis, qui hoc scripsit die et anno quo supra: Francisco Miquel Rossell (1945 et 1947, doc. 692).

${ }^{23}$ Bernardus Berengarii, publicus scriptor, rogatus, hoc scripsit vice Guilelmi Regis, notarii, et hoc sig-(SM)num fecit, ADPO, Fonds de l'Hôpital d'Ille, 3B495bis.

${ }^{24}$ Bernardus Berengarii, levita, rogatus atque jussus, hanc cartam scripsit die et anno (SM) quo supra, ADPO, Hp191, fol. 292-v; 2Hdtp21, 2Hdtp34.

${ }^{25}$ Petrus, diachonus, scripsit hoc vice Bernardi Berengarii (SM) cum literis suprascriptis in $V^{a}$ linea. Bernardus Berengarii, publicus scriptor, subscripsit et hoc sig-(SM)-num fecit, ADPO, Hp191, fol. 99.

${ }^{26}$ Como o estipulam os registros que se referem à criação de notários. Também, no documento de concessão do notariado de Vilafranca del Penedès, em 1188, o rei de Aragão ordenou que todo instrumento redigido por alguém que não fosse aquele a quem ele concedeu o ofício ou o seu substituto, fosse destituído de valor, a menos que ele portasse a subscrição deste últimos: (...) ullum valorem habebit, cujuscumque generis instrumentum ab eo factum, nisi isdem Bernardus aut ille qui ab eo fuerit substitutus subsignaverit ipsum.

${ }^{27}$ Sobre estas questões, ver Karim Sïdi (2005-2006).

${ }^{28}$ Petrus de Verneto, presbiter, publicus scriptor, scripsit hoc, rogatus, vice Guilelmi Regis notarii et hoc sig(SM)-num fecit, ADPO, 2Hdtp3, 2Hdtp22, 1B53, 1B7 et Hp191, fol. 59v-60.

${ }^{29}$ Poncius de Bajolis scripsit hoc vice Petri de Verneto et hoc sig-(SM)-num fecit. Petrus de Verneto, presbiter, publicus scriptor, subscripsit et hoc sig-(SM)-num fecit, ADPO, 2Hdtp34.

${ }^{30} \mathrm{Em}$ 1178, o bispo de Béziers concedeu o tabelionato de sua cidade a Bernat de Caussiniojouls, ver Chastang (2002, p. 295).

${ }^{31}$ André Gouron (1957, p. 113) constata que "le notariat public ne se généralisera entre Rhône et Aude que pendant le dernier quart du XII ${ }^{\mathrm{e}}$ siècle".

${ }^{32}$ Em À Saint-Gilles, no Rhône, o profissional Raymond Boudon se intitulava scriptor et publicus notarius a partir de 1171. Ver Émile-G. Léonard (1932, p. L).

${ }^{33}$ Notários aí subscreveram um registro em março de 1185, ver Yves Dossat (1956, p. 182).

${ }^{34}$ Montpellier, cidade universitária frequentada por grandes juristas italianos, dentre os quais os célebres Azon e Placentino, conheceu uma implantação particularmente precoce do notariado por volta de 1140, ver: Franck Bréchon (1995, p. 161-172).

${ }^{35}$ Um notário aparece regularmente na cidade de Agde a partir de 1175, ver Gouron (1957, p. 113,) e Chastang (2002, p. 294).

${ }^{36}$ Egidius, publicus Narbone notarius, Doat, vol.55, fol. $245 \mathrm{v}$.

${ }^{37}$ Um tabellio publicus exercia o ofício em Toulouse em 1179, ver Gouron (1963, p. 59).

${ }^{38}$ A subscrição do padre Ermengau, escrevente público de Gérone, figura na fórmula de autenticação do vidimus, datado de 8 de outubro de 1187, do testamento do conde de Roussillon, Geraldo II, ADPO, 1 B5.

${ }^{39}$ ADPO, 1B84. Em julho de 1208, este notário tinha um substituto: Sig+num Guillermi Bernardi, publici notarii. Arb(e)rtus scripsit hec vice Guillermi Bernardi in die et anno quo supra, ADPO, 1B412, fol. 159v.

${ }^{40}$ Juramento de fidelidade prestado em 18 de junho de 1205 por Guilherme de Canet ao bispo de Elne, Guilherme: Sancius subdiaconus, capud scole, publicus scriptor, qui hoc totum audit et audivit rogatus atque jussus scripsit et hoc signum fecit, ADPO, G23, fol. 5v-6.

${ }^{41}$ Berengário, predecessor de Sancho, assim redigiu uma transação em outubro de 1200: Berengarius caputscole hoc (SM) scripsit, ADPO, G132.

${ }^{42}$ Jacobus, subdiachonus, hoc scripsit vice Sancii caputscole (SM), ADPO, G57.

${ }^{43}$ Jachobus levita scripsit hoc rogatus vice Sancii caputscole (SM) die et anno quo supra, ADPO, $1 \mathrm{~B} 68$.

${ }^{44}$ Jacobus, levita, caput scole, scripsit hoc, rogatus... et hoc signum (SM) fecit, ADPO, Hp191, fol. 63.

${ }^{45}$ João era provavelmente oriundo de uma linhagem de modestos cavaleiros, dos quais outro representante, Pedro de Canohès, fez, uma geração mais tarde, uma longa carreira administrativa no seio da ordem do Templo.

${ }^{46}$ Johannes de Canois, subdiachonus, publicus scriptor et caputscole hanc cartam scripsit et hoc sig-(SM)-num fecit, ADPO, G132.

R. Fac. Dir. UFG, v. 39, n.2, p. 43 - 86, jul. / dez. 2015 
${ }^{47}$ Assim, na parte inferior de um registro datado de 30 de junho de 1229: Johannes de Canois caputscole hanc cartam scripsit et hoc sig-(SM)-num fecit, ADPO, G115.

${ }^{48}$ No dia 20 de julho de 1240 , ele redigiu o testamento do cavaleiro Pôncio de Ortaffa, ADPO, $1 E 626$.

${ }^{49}$ Entre os manuscritos medievais conservados na midiateca de Perpignan destaca-se uma Gramática de Priciano, autor do século VI, cujos ensinamentos eram incontornáveis durante a Idade Média. Datada do século XIII, esta copia em pergaminho, certamente, serviu a educar gerações de jovens clérigos roussillonnais, talvez, até mesmo junto à escola catedral, quem sabe?

${ }^{50}$ Como, por exemplo, em junho de 1254: Ego Fferrarius de Cereto, clericus Elne et scriptor publicus auctoritate domini Berengarii Elne episcopi, hanc cartam scripsi et hoc signum fecit, ADPO, G23; ou ainda, em janeiro 1257: Ego P. Torti, clericus Elne, hanc cartam laudatam in posse Raymundi, prepositi Elne, scriptoris publici, mandato A. Torrentis, clerici Elne et scriptoris publici, scripsi et hoc sig-(SM)-num fecit. Idem Arnaldus Torrentis, clericus Elne et scriptor publicus auctoritate domini Br. Elne episcopi subscripsit et hoc sig-(SM)num fecit, ADPO, G33.

${ }^{51}$ Muito provavelmente, este padre ocupava o posto da igreja Saint-Jean, que permaneceu a única paróquia de Perpignan até a fundação da igreja São Jaime, pelo rei Jaime I, em 1244.

${ }^{52}$ Poncius de Bajolis scripsit hoc vice Petri de Verneto et hoc sig-(SM)-num fecit. Petrus de Verneto, presbiter, publicus scriptor, subscripsit et hoc sig-(SM)-num fecit, ADPO, $2 \mathrm{Hdtp} 34$.

${ }^{53}$ Do mesmo modo, em setembro de 1208, Poncius de Bajolis, scriptor publicus, hoc scripsit vice Berengarii de Crassa et hoc signum (SM) fecit. Berengarius de Crassa, publicus scriptor, subscripsit et hoc sig-(SM)-num fecit, ADPO, Hp191, fol. 235.

${ }^{54}$ Ego, Berengarius de Grassa, canonicus dicte ecclesie et publicus scriptor, hoc laudo et hoc sig-(SM)-num facio, ver o registro $\mathrm{n}^{\circ} .1$ publicado em anexo.

${ }_{55}$ Poncius de Bajolis, scriptor publicus et canonicus ecclesie Sancti Johannis Perpiniani, hoc scripsit vice Berengarii de Crassa, et rasit et emendavit in VII linea, et in XI ${ }^{a}$, et in XVIIII ${ }^{a}$, et hoc sig-(SM)-num fecit. Berengarius de Grassa, publicus scriptor, subscripsit et hoc sig-(SM)-num fecit, ADPO, Hp186.

${ }^{56}$ Poncius de Bajolis, scriptor publicus vice gerens Berengarii de Crassa, hoc scripsit, rogatus, et hoc sig-(SM)num fecit, ADPO, Hp191, fol. 195v.

${ }^{57}$ Petrus Raymundi, qui hoc scribi vicem gerens Berengarii de Grassa, publici Perpiniani notari-(SM)-i, ADPO, Hp191, fol. 407.

${ }^{58}$ Ego Raimundus de Furchis hoc scripsi dictante magistro meo Raymundo scriptore. Ego RAIMUNDUS presbiter, publicus scriptor vice Berengarii de Crassa, sic feci scribere et fe[ci] hoc (SM) signum, ADPO, H288.

${ }^{59}$ Ego Bernardus Berriachi hoc testamentum scri[psi dictante] magistro meo Bernardo Jugna. Bernardus Jugna, rogatus, hoc testamentum sic feci scribere vice Berengarii de Crassa, publici notarii Perpiniani, et feci hoc (SM)-num, ADPO, 2Hdtp34.

${ }^{60}$ Assim, na parte inferior de um registro datado de 19 de março de 1221: Poncius de Bajolis, scriptor publicus mandato domini Nunonis Sancii, hoc scripsit, rogatus,... et hoc sig-(SM)-num fecit, ADPO, Hp191, fol. 188v. Nuno Sancho, filho do conde Sancho, era o sobrinho germânico do rei de Aragão, Pedro II, que lhe tinha concedido, em caráter vitalício, os condados de Roussillon e de Cerdagne, assim como o Conflent e o Vallespir, no mês de fevereiro de 1212. Após sua morte, ocorrida em janeiro de 1242, os condados norte catalães foram diretamente administrados pelo rei Jaime I. Sobre esta personagem, ver Rodrigue Tréton e Robert Vinas (no prelo).

${ }^{61}$ Um dos últimos registros realizados por Pôncio de Bajoles, datado de 4 de março de 1225, foi feito após sua morte por seu sucessor Pedro de Riu: Petrus de Rivo, scriptor publicus mandato domini Nunonis Sancii, scripsit post mortem Poncii de Bajolis hoc instrumentum laudatum in vita sua et hoc sig-(SM)-num fecit, ADPO, 2Hdtp3. Pedro de Riu estava no posto ao menos desde 7 de abril de 1225, ADPO, 1 B53.

${ }^{62}$ Poncius de Bajolis, scriptor publicus, tenens scribaniam Perpiniani pro domino Nunone, hoc scripsit rogatus, et hoc sig-(SM)-num fecit, ADPO, G57.

${ }^{63}$ Johannes Felicis, scriptor publicus, tenens locum Guilelmi Jacobi in scribania de Ynsula, ADPO, Fundos do Hospital d'Ille, 3B411; Arnaldus Sestrada, scriptor publicus auctoritate domini Raymundi Elnensis episcopi, tenens scribania de Insula pro domino Petro de Fenoleto, ADPO, Fundos do Hospital de Ille, 3B536.

${ }^{64}$ Em outubro de 1194, o rei Afonso II concedeu à igreja de Santa Maria de Montblanch e a seu capelão: scribaniam publicam de villa nostra de Montisalbi et tocius parroquie in perpetuum, (In: HUICI MIRANDA \& CABANES PECOURT, 1977, doc. $\mathrm{n}^{\circ}$. 555, p. 13-14).

${ }_{65}$ Assim, por exemplo, em 1188, no registro evocado, pelo qual o rei Afonso II concedeu à igreja de Vilafranca del Penedès o notariado desta via: (...) concedo (...) notariam totam seu scribaniam ville jamdicte et territorii ejus et parrochie nunc habite vel habende (...); do mesmo modo, em 5 de janeiro de 1254, Jaime I concedeu à comunidade dos habitantes de Villefranche-de-Conflent: (...) totam scribaniam sive notariam publicam Villefranche predicte et tocius Confluentis (...) (In: B. ALART, 1874, p. 208).

${ }^{66}$ ADPO, 1B357, fol. 89. 


\section{PRELÚDIO A HISTÓRIA DO NOTARIADO PÚBLICO EM PERPIGNAN E NO CONDADO DE ROUSSILLON (1184-1340)}

${ }_{67}^{67}$ ADPO, 1B423, fol. 224v.

${ }^{68}$ ADPO, 1J76.

${ }^{69}$ Guilelmus Fortis, precentor et publicus scriptor, jussus atque rogatus scripsit et hoc signum (SM) fecit, ADPO, $1 \mathrm{~B} 47$.

${ }^{70}$ ADPO, $1 \mathrm{~B} 47$.

${ }^{71}$ Guillemus Fortis, caputscole de Turrilliis et publicus scriptor, jussus atque rogatus, hanc cartam scripsit et hoc signum - (SM) - fecit, ADPO, 1B48.

${ }^{72}$ ADPO, 1B47 e 1B48.

${ }^{73}$ Et si nebulam vel aquam vel petram vel ost vel cavalchatas sive ignem supervenerint ad predictum expletum, illud defectum minuatur de predictis $L X^{a}$ solidis ad noticiam proborum hominum ville de Turrillis, ADPO, $1 \mathrm{~B} 48$.

${ }^{74}$ Guilelmus Firmacius, scriptor publicus, scripsit hoc sicut fuit fideliter notatum a Guilelmo Forti quondam et in manu sua laudatum, qui, mortem preoccupatus, scribere hoc nequivit, et hoc signum (SM) fecit, ADPO, $1 \mathrm{~B} 48$.

${ }^{75}$ ADPO, 3E1/1 a 3E1/17.

${ }^{76}$ Jean-Louis Gaulin (2004, p. 69) apresenta um levantamento das mais antigas menções de registros de breves na Península Italiana: Pávia (1206), Bologna (1214) e Roma (1220).

${ }^{77}$ Constatações similares foram formuladas a partir dos registros provençais, ver Franck Brechon (1995). Parece, por outro lado, que, na Itália, a situação era mais contrastada. Os arquivos de Gênova conservam provavelmente os mais antigos registros notariados em papel do Ocidente, seu proprietário exercia o ofício entre 1154 e 1164 (STIENNON, 1991, p. 181). Em Bologna, o papel não foi sistematicamente adotado pelos notários: o segundo registro de breves do notário de Bologna Manfredo da Salla (1264-1270), estudado por Jean-Louis Gaulin (2004, p. 71), era constituído de onze cadernos de pergaminho.

${ }^{78}$ Foram os árabes que introduziram o papel na Península Ibérica no século X. Eles instalaram aí as mais antigas papelarias do continente em Jativa, próximo de Valencia. Ver: Oriol Valls i Subira (1978-1980, p. 94-95).

${ }_{79}^{79}$ Ver, por exemplo, as estimulantes contribuições reunidas na obra co-dirigida por François Menant et Odile Redon (2004).

${ }^{80}$ Decretalium Gregorii papae IX, Compilationis, lib. III, tit. L, cap. VIII.

${ }^{81}$ Redigidas em 1288, os estatutos do notariado da cidade de Bologna formularam muito claramente este argumento: (...) cum clerici non subjaceant justicie gladii temporalis, et ideo eorum excessus puniri non possent per judices seculares, dicimus et ordinamus quod aliquis clericus vel ad aliquos ordines sacros vel clericatus admissus non sit nec esse vel recipi possit de societate vel collegio nostro... (In: GAULIN, 2004, p. 61, nota 32).

${ }^{82}$ Item statuimus quod nullus clericus portans coronam vel in sacris ordinibus constitutus sit publicus notarius, nec faciat instrumenta publica sive testamenta aut cartas nupciales vel alios contractus, immo illa ab omni judicio et credulitate penitus repellantur. Et si post assumptum officium tabellionatus clericus fiat vel coronam portaverit, tabellionatus officio privetur. Et nullus in scriptorem publicum statuatur, nisi in eadem villa vel suburbiis habuerit proprium domicilium. Nec sit publicus notarius nisi vicesimum quintum annum excesserit; et tunc vicario presentetur et a duobus litteratis juris de ejus sciencia scrutetur, et si sufficiens ad instrumenta conficienda invenitur, recipiatur et juret se esse fidelem et legalem in suo officio, (In: HUICI MIRANDA \& CABANES PECOURT, vol II, 1976doc. $\mathrm{n}^{\circ} .471$ p. 280-281).

${ }^{83}$ Estes exemplos são suficientes para demonstrar isso: Berengarius Miafredus, capellanus de Turano, scriptor publicus, subscripsi vice Guilelmi Torta auctoritate domini B. Elnensis episcopi, em dezembro de 1265, ADPO, 1B37; Guilelmus Pedregarii, sacerdos atque sacrista de Malleolis, scriptor publicus auctoritate domini Elnensis episcopi, hoc scripsit et suprascripsit in XII linea et hoc sig-(SM)-num fecit, em janeiro de 1269, ADPO, Hp191, fol. 241; Clausum et subsignatum manu Petri Reinaldi, clerici et scriptoris Elne auctoritate domini Raimundi, Dei gracia Elnensis episcopi, em agosto de 1299, Bernardus de Luparia, capellanus ecclesie de Moleto, scriptor publicus auctoritate domini Elnensis episcopi, subscripsit et hoc sig-(SM)-num fecit, em novembro de 1301, ADPO, 1J790.

${ }^{84}$ Assim, por exemplo, Pedro de Riu, escrevente público de abril de 1225 a outubro de 1233, subscreveu do modo seguinte: Petrus de Rivo, scriptor publicus mandato domini Nunonis Sancii, subscripsit et hoc sig-(SM)num fecit, ADPO, Hp191, fol. 260; seu sucessor, Pedro Calvet, subscreveu de junho de 1234 a janeiro de 1237: Petrus Calvetus, scriptor publicus mandato domini Nunonis Sancii, subscripsit et hoc sig-(SM)-num fecit, ADPO, Hp191; Bernat Sabors subscreveu da seguinte maneira em fevereiro de 1237: Bernardus Sabors, hanc cartam subscripsi mandato domini Nunonis Sancii et feci hoc sig-(SM)-num. Curiosamente, este regente da escrivania de Perpignan apenas precisou sua qualidade de escrevente publico à partir de dezembro de 1238: Ego, Bernardus Sabors, scriptor publicus, hanc cartam subscripsi mandato domini Nunonis Sancii, et feci hoc sig(SM)-num, ADPO, Hp186.

${ }^{85}$ Bernardus Amalrici, sacrista de Orulo, scriptor publicus, subscripsit hanc cartam et sic scribi fecit, et auctoritate domini B., Elnensis episcopi, hoc sig-(SM)-num fecit, ADPO, 1B63.

R. Fac. Dir. UFG, v. 39, n.2, p. 43 - 86, jul. / dez. 2015 
${ }^{86}$ Jacobus Peregrini, sacerdos atque sacrista de Malleolis auctoritate domini B. Elenensis episcopi, subscripsit et hoc sig-(SM)-num fecit, ADPO, Hp191, fol. 202v; Ego Petrus Maurelanus, presbiter, scriptor publicus auctoritate domini B. Elnensis episcopi, hanc cartam scripsi et hoc meum signum (SM) feci.

${ }^{87}$ Petrus Calvetus, scriptor publicus, mandato domini Nunonis Sancii scripsit, et hoc sig-(SM)-num fecit , ADPO, $1 \mathrm{~B} 9$.

${ }^{88}$ Petrus Calvetus, scriptor publicus Perpiniani, scripsit et hoc sig-(SM)-num fecit, ADPO, Hp188.

${ }^{89}$ Raimundus Carles, notarius publicus Perpiniani, hoc translatum subscripsit et hoc sig-(SM)-num fecit, Arxiu Capitular de la Catedral de Barcelona, 4-82-60.

${ }^{90}$ Em fevereiro de 1261: Guilelmus Martinus, scriptor publicus de Clairano, hanc cartam scripsit et hoc sig(SM)-num fecit, ADPO, Hp191, fol. 36v.

${ }^{91}$ Parece que os escreventes públicos de Collioure seguiam os mesmos costumes de Perpignan, assim, em novembro de 1250: Ego, Petrus Augerii, Coquiliberi scriptor publicus, hanc cartam scripsi et sig-(SM)-navi, ou em dezembro de 1267: Petrus Sansa, scriptor publicus Cauquiliberi, scripsit (et) hoc sig-(SM)-num fecit, ADPO, Hp191, fol. 121-v.

${ }^{92}$ Em outubro de 1265: Bernardus Antoni, scriptor publicus de Salsis, subscripsit et hoc sig-(SM)-num fecit, ADPO, $1 \mathrm{~B} 37$.

${ }^{93}$ No dia 2 de maio de 1257, Jaime I concedeu aos habitantes do castrum e da vila de Thuir que os testamentos e outros instrumentos públicos, realizados no estudo de Thuir, tivessem a mesma força que aqueles lavrados no estudo de Perpignan e que eles tivessem os mesmos privilégios concedidos por ele e seus predecessores a Perpignan, ADPO, 1B357, fol. 89.

${ }^{94}$ ADPO, 1B346, fol. 128v-132.

${ }^{95}$ Item, voluerunt, laudaverunt et diffinierunt dicti domini archiepiscopus et abbates quod ipse dominus rex et dominus infans et successores in castris, villis et aliis locis propriis que et quas ad manus suas nunc tenent et tenebunt quoquo titulo in Elnensis diocesis, et non in aliis locis dicte diocesis Elnensis, semper decetero ponant et instituant notarios publicos et scriptores auctoritate propria predicto domino Elnensis episcopo minime requisito. Item, eciam dominus Elnensis episcopus et successores sui in omni terra sua et in aliis locis Elnensis diocesis preterquam in terra domini regis quam ad manum suam tenet vel tenebit, idem dominus rex aut dominus infans vel successores eorum quoquo titulo adquirendo per quem transfferatur dominium utile vel directum ponat inquam idem dominus Elnensis episcopus et successores sui notarios quos voluerit, clericos vel laycos; notarii vero quos dominus Elnensis episcopus possuit seu instituit in terra dicti domini regis quam tenet dictus dominus infans in suo remaneant officio quamdiu vixerunt de licencia et voluntate dicti domini infantis et sic suberant dicto domino Elnensis episcopo, ita subeant domino regi et domino infanti nomine et auctoritate domini regis et domine infantis faciant instrumenta, scribant, subscribant et signent et dent ipsi domino regi et domino infanti censuum annum que dicto domino Elnensis episcopo prius dabant.

${ }^{96}$ Em Ille, no dia primeiro de janeiro de 1269: Raymundus Vel, scriptor publicus de Ynsula auctoritate domini Berengarii Dei gracia episcopi Elnensis, hanc cartam scripsit et hoc sig-(SM)-num fecit; em 14 de abril de 1297: Arnaldus Sestrada, scriptor publicus de Insula auctoritate domini regis Majoricarum, hanc cartam scripsi et rasi et emendavi in decima linea ubi dicitur "et promito", et hoc sig-(SM)-num feci. Uma nova mudança ocorreu neste burgo no começo do século XIV, após a concessão da escrivania de Ille ao senhor Pedro de Fenouillet: Arnaldus Cestrada, scriptor publicus auctoritate domini Raymundi Elnensis episcopi, tenens scribania de Insula pro domino Petro de Fenoleto, hanc cartam scripsi et suprascripsi in IIII ${ }^{a}$ linea Gili, partes et hoc sig-(SM)-num fecit, ADPO, Fundos do Hôpital de Ille, 3B331, 1B9 e 3B536. Em Prats, no mês de abril de 1245: Bernardus Abus, scriptor publicus de Prats, auctoritate domini Bernardi, Dei gratia Elnensis episcopi, hec scripsit; e em junho de 1303: Eximini Marti auctoritate regia notarii publici ville et vallis de Pratis qui predicta fieri recepta in suo originali privilegio hec scribi feci et clausi die, anno testibus decreto quibus superius, (In: MONTSALVATJE Y FOSSAS, 1889-1920, vol. 24, app. nº. IX, p. 324-325; cf. ADPO, Livre rouge de Prats de Mollo, fol. 29).

${ }^{97}$ Archivo de la casa ducal de Médinacelli, Comtes d'Empúries, $\mathrm{n}^{\circ} .51$.

${ }^{98}$ ADPO, 1B51.

${ }^{99}$ No dia 22 de fevereiro de 1265: Johannes Corbera, scriptor publicus Turriliis auctoritate domini Ber[engarii], Elnensis episcopi, subscripsit et hoc signum (SM) fecit, ADPO, $1 \mathrm{~B} 51$.

${ }^{100}$ No dia 13 de julho de 1290: Guilelmus Alamanni, scriptor publicus de Turrilliis auctoritate domini regis Majoricarum, hanc cartam scripsit et hoc sig-(SM)-num fecit, ADPO, Hp258.

${ }^{101}$ É o caso de Vallespir, onde os viscondes de Castelnou e os senhores de Serralongue-Corsavy exerciam a autoridade.

${ }^{102} \mathrm{O}$ batlle catalão, equivalente ao bailli (bajulo) francês, é um oficial ao qual o senhor jurisdicional confiava a administração de uma localidade lhe delegando suas competências nos assuntos de polícia e justiça. 


\section{PRELÚDIO A HISTÓRIA DO NOTARIADO PÚBLICO EM PERPIGNAN E NO CONDADO DE ROUSSILLON (1184-1340)}

${ }^{103}$ Os bons homens ou prud'hommes eram, de maneira geral, os membros mais influentes de uma comunidade urbana ou aldeã. Designados em função de critérios de fortuna e de experiência pessoal, eles tinham uma função representativa e consultiva.

${ }^{104}$ A universidade designava o conjunto da comunidade dos habitantes.

${ }^{105}$ Subscrição na parte inferior de um registro de 23 de agosto de 1228: Petrus Calvetus scripsit hoc vice Petri de Rivo et hoc sig-(SM)-num fecit, ADPO, $1 \mathrm{~B} 9$.

106 ADPO, 1B83.

107 Petrus Calvetus, scriptor publicus mandato domini Nunonis Sancii, scripsit et hoc sig-(SM)-num fecit, ADPO, Hp191.

${ }^{108}$ Assim, no dia 10 de março de 1242: Petrus Calvetus, scriptor publicus Perpiniani, scripsit et hoc sig-(SM)num fecit, ADPO, Hp191, fol. 430.

${ }^{109}$ Pedro Calvet instrumentou ainda no dia 17 de junho de 1257, ADPO, Hp145, fol. 3v; a mudança interveio antes de 18 de julho, data que Guilherme Aimeric instrumentou uma doação antes de subscrever: Guilelmus Aimerici, scriptor publicus Perpiniani, subscripsit et hoc sig-(SM)-num fecit, ADPO, 1B49. Guilherme Aimeric ainda subscreveu em 3 de janeiro de 1258, ADPO, Hp191 fol. 224.

${ }^{110}$ Ele expediu um registro em 29 de janeiro de 1258, ADPO, Hp191, fol. 384v.

${ }^{111}$ A importância da devoção que os perpignanais dedicavam ao culto de seu santo patrono se encontra nas armas do consulado de Perpignan que representam a figura de São João Batista sobre um escudo de ouro com quatro colunas vermelhas, armas da dinastia condal de Barcelona. A escolha da data de 24 de junho como o término do contrato se remete, portanto, ao simbolismo do ciclo urbano.

${ }^{112}$ No dia 20 de junho de 1330, os membros do conselho geral da vila de Puigcerdà nomearam por um ano, dois notários e dois aprendizes que estavam a cargo da escrivania pelo ano que começava na próxima festa de São João Batista, em junho, ADPO, 7J40.

${ }^{113}$ Assim, em 11 de fevereiro de 1252: Ego, Arnaldus Mironi, hanc cartam scripsi mandato Guilelmi de Frexaneto, ADPO, Hp191, fol. 182.

${ }_{114}^{11}$ ADPO, 1B15, fol. 117v.

${ }^{115}$ Ego, Petrus Faber de Capcirio, hanc cartam scripsi mandato Arnaldi Mironi. Arnaldus Mironi, scriptor publicus Perpiniani, subscripsit et hoc sig-(SM)-num fecit, ADPO, $1 \mathrm{~B} 72$.

116 A origem de Raimundo Eimeric nos é desconhecida. Ele não aparece na documentação perpignanaise antes desta data.

${ }^{117}$ Em 18 de outubro de 1266: Ego, Petrus Amorosii, hanc cartam scripsi mandato Arnaldi Mironi, et supra scripsi in VII linea "foriscapium”. Arnaldus Mironi, scriptor publicus Perpiniani, subscripsit vice Raymundi Eymerici, et hoc sig-(SM)-num fecit, ADPO, Hp191, fol. 346v.

${ }^{118}$ A última evocação reconhecida de Raimundo Eimeric encontra-se no escatocolo de um registro do mês de agosto de 1268, ADPO, Hp191, fol. 415.

${ }^{119}$ Ele retomaria novamente a cabeça da escrivania de Perpignan em agosto de 1275; depois, exerceria o ofício intermitentemente até 1288. Encontra-se um Arnau Miró à cabeça do notariado perpignanais em 1298, sem que se possa determinar se se tratava da mesma pessoa ou de um parente homônimo, filho ou sobrinho.

${ }^{120}$ Arnaldus Mironi, scriptor publicus Perpiniani, subscripsit post mortem Raymundi Eymerici condam scriptoris publici Perpiniani hoc instrumentum in posse dicti Raymundi Eymerici condam receptum et laudatum, et hoc sig-(SM)-num fecit, ADPO, Hp191, fol. 323.

${ }^{121}$ Ego, Petrus Fabri de Capcirio, scriptor publicus Perpiniani, hoc instrumentum, receptum et laudatum in posse Bernardi Caruli, auctoritate mihi concessa a Petro Rubei, judice ordinario Perpiniani et Rossilionis, et a Sancio de Trilario, tenente locum Martini de Trilario, bajuli Perpiniani, et a predicto Bernardo Caruli, subscripsi et hoc sig-(SM)-num feci, ADPO, Hp191, fol. 42v. Bernardo Carles, escrevente público, teria a escrivania de Perpignan a partir do mês de novembro de 1272.

${ }^{122}$ Em 1261, um casal de Vic confiou seu filho, Pedro, a mestre Raimundo, escrevente, por uma duração de quatro anos, a contar do próximo dia de São Vicente, a fim de que ele lhe ensinasse o ofício de escrevente, (CARRERAS Y CANDI, 1913, p. 774).

${ }^{123}$ Esta concessão foi confirmada pelo infante Jaime I em fevereiro de 1270, Cartulaire municipal de Vinça, ADPO, 183EDT1, fol. 6.

${ }^{124}$ scribaniam ville Podiiceritani et tocius Ceritanie, (In: HUICI MIRANDA \& CABANES PECOURT, vol. V, 1988, doc. $\mathrm{n}^{\circ}$. 1411).

${ }^{125}$ Por exemplo, em 1288: Eymericus de Pratis notarius publicus de Corneliano auctoritate domini camerarii monasterii ejusdem loci.

${ }^{126}$ Damus etiam vobis et assignamus pro cambio jam dictarum villarum quadringentos solidos malgarenses censuales imperpetuum super redditibus et exitibus notarie seu scribanie nostre ville Perpiniani, quos accipiatis in festo Natalis Domini annuatim (In: HUICI MIRANDA CABANES PECOURT, vol. II, 1976, doc. $\mathrm{n}^{\circ}$. 875).

R. Fac. Dir. UFG, v. 39, n.2, p. 43 - 86, jul. / dez. 2015 
127 A título de comparação, eis as cifras das outras escrivanias reais: Collioure : 75 L, Le Boulou : 8 L, Calce : 10 L, Claira : 10 L, Puigcerdà 15 L, Villefranche-de-Conflent 30 L $10 \mathrm{~s}$.

${ }^{128}$ Quadro geral dos notários que exerciam o ofício em 1906 na $1^{\text {a }}$. circunscrição do departamento dos PyrénéesOrientales e das escrituras de notarios contidas em seus estudos, Perpignan, 1907, citado por Denis Fontaine et Christine Langé (2006, p. 103).

${ }^{129}$ ADPO, 1B94, fol. 15-v.

${ }^{130}$ ADPO, 1B94, fol. 16-17.

${ }^{131}$ Et statuimus insuper et ordinamus quod omnes notarios et scriptores regni et terrarum nostrarum publicum notarie officium exercentes in prothocollis et notis officiorum suorum scribant large et prolixe totum tenorem instrumentorum, contractuum quorumcumque, testamentorum, codicillorum et aliorum quorumlibet absque verbo et cetera sine abreviatura ac subintelligencia quacumque, sich quod idem sit tenor per omnia prothocolli et instrumenti in mundum reddacti.

Artigo recebido em 26 de novembro de 2015 e aceito em 15 de dezembro de 2015 